\title{
AN INDEX OF ECOLOGICAL INTEGRITY FOR THE MISSISSIPPI ALLUVIAL PLAIN ECOREGION: INDEX DEVELOPMENT AND RELATIONS TO SELECTED LANDSCAPE VARIABLES
}

Water-Resources Investigations Report 03-4110

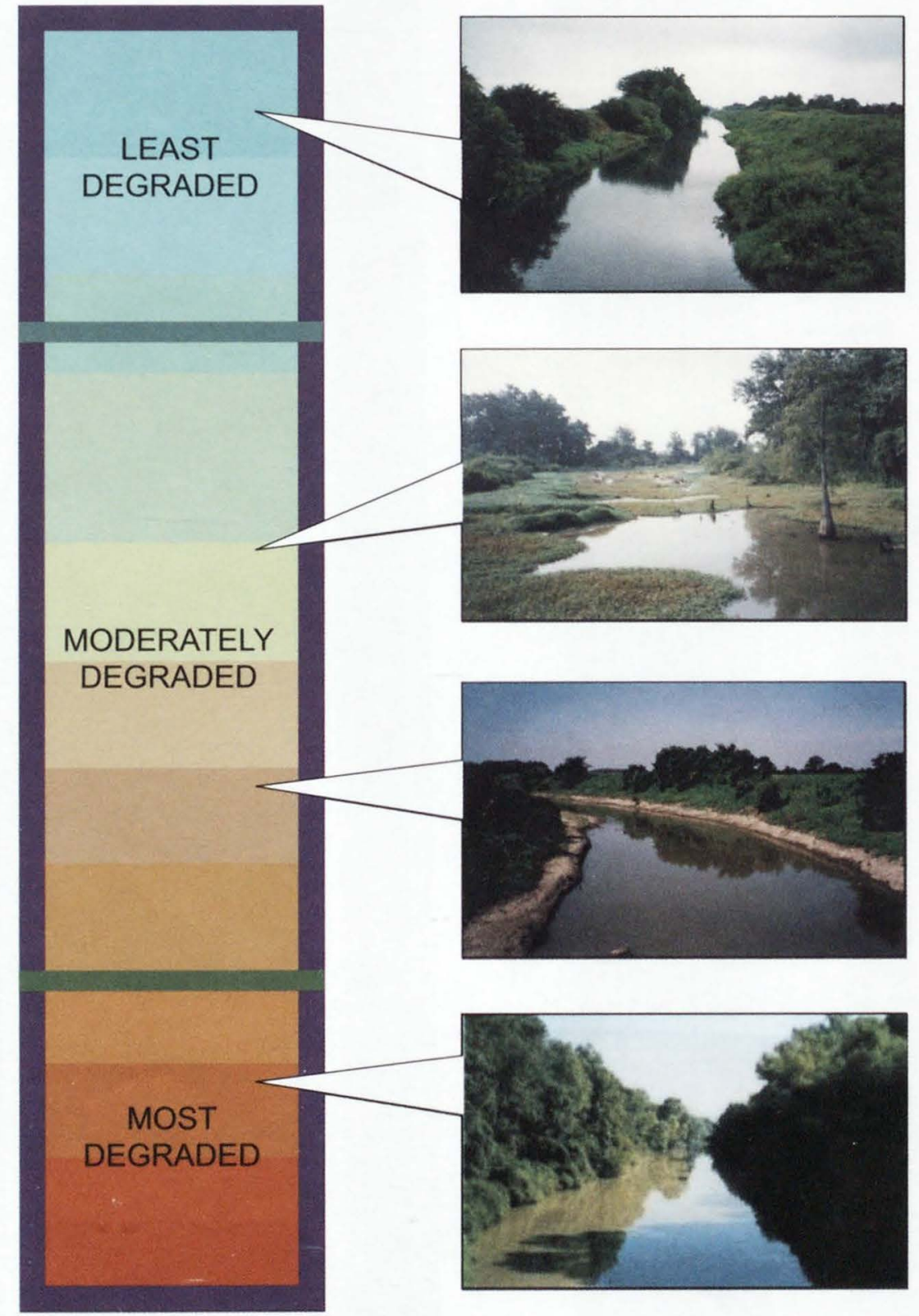

US GEOLOGICAL SURVEY IESTON. VA

NOV 172003

\section{SR}

LIBRARY

U.S. Department of the Interior

U.S. Geological Survey 

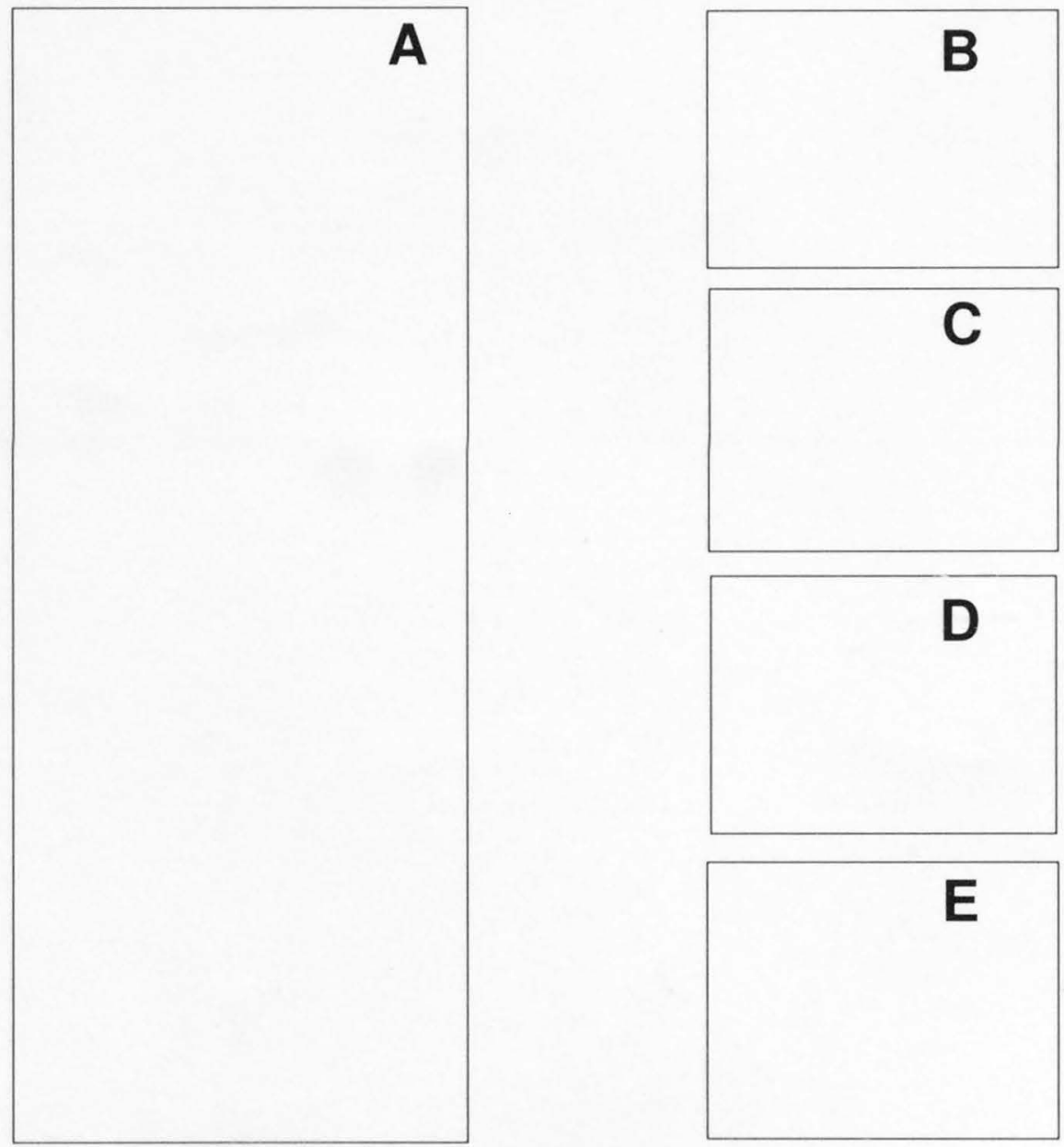

Report cover: (A) Schematic of index concept

(B) Main Ditch at Highway 153 near White Oak, Missouri

(C) Silver Creek near Bayland, Mississippi

(D) Tyronza River near Twist, Arkansas

(E) Tensas River at Tendal, Louisiana

Photographs by Michael Manning and Brian Caskey, U.S. Geological Survey 


\section{AN INDEX OF ECOLOGICAL INTEGRITY FOR THE MISSISSIPPI ALLUVIAL PLAIN ECOREGION: INDEX DEVELOPMENT AND RELATIONS TO SELECTED LANDSCAPE VARIABLES}

By B.G. Justus

U.S. GEOLOGICAL SURVEY

Water-Resources Investigations Report 03-4110 


\section{U.S. DEPARTMENT OF THE INTERIOR}

GALE A. NORTON, Secretary

U.S. GEOLOGICAL SURVEY

Charles G. Groat, Director

For additional information write to:

\section{District Chief}

U.S. Geological Survey, WRD

401 Hardin Road

Little Rock, Arkansas 72211
Copies of this report can be purchased from:

U.S. Geological Survey

Branch of Information Services

Box 25286

Denver Federal Center

Denver, Colorado 80225 


\section{CONTENTS}

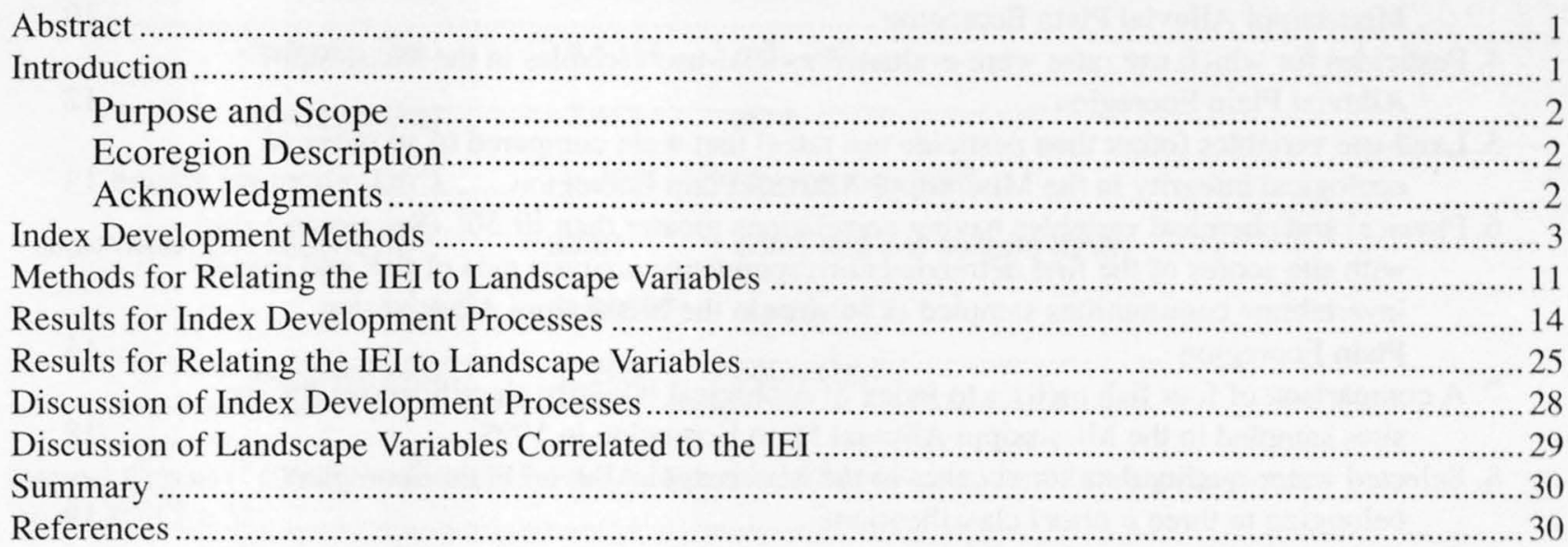

\section{ILLUSTRATIONS}

Figure 1. Map showing location of sites sampled in the Mississippi Alluvial Plain Ecoregion from 1996 to 1998

2. Map of the Mississippi Embayment Study Unit showing Crowleys Ridge and part of the Mississippi Alluvial Plain Ecoregion

3. Graph showing detrended correspondence analysis ordination plot of sites scores on the first two axes for fish community samples collected at 36 sites in the Mississippi Alluvial Plain Ecoregion.

4. Graph showing detrended correspondence analysis ordination plot of sites scores on the first two axes for macroinvertebrate community samples collected at 36 sites in the Mississippi Alluvial Plain Ecoregion

5. TWINSPAN dendogram showing first separation of fish community samples collected at 36 sites in the Mississippi Alluvial Plain Ecoregion in 1998.

6. TWINSPAN dendogram showing first separation of macroinvertebrate community samples collected at 36 sites in the Mississippi Plain Ecoregion in 1997.

7. Graph showing comparison of two scoring methods evaluated for an index of ecological integrity in the Mississippi Alluvial Plain Ecoregion ....

8. Map showing index of ecological integrity scores for 36 sites in the Mississippi Alluvial Plain Ecoregion

9. Scatter plot comparing index of ecological integrity scores to the percent of Holocene deposits in the basins at 36 site samples in the Mississippi Alluvial Plain Ecoregion...

10. Scatter plot comparing index of ecological integrity scores to the amount of profenofos applied in 36 stream basins in the Mississippi Alluvial Plain Ecoregion

11. Scatter plot comparing the percentage of the basin in which cotton is grown and the amount of profenofos applied in 34 stream basins in the Mississippi Alluvial Plain Ecoregion. 


\section{TABLES}

Table 1. Physical information for sampling sites in the Mississippi Alluvial Plain Ecoregion.....

2. Chemical and physical metrics considered as candidates for an ecological index at 36 streams sampled in the Mississippi Alluvial Plain Ecoregion from 1995 to 1998

3. Fish metrics considered as candidates for an index of ecological integrity in the Mississippi Alluvial Plain Ecoregion

4. Pesticides for which use rates were evaluated as land-use variables in the Mississippi Alluvial Plain Ecoregion

5. Land-use variables (other than pesticide use rates) that were compared to an index of ecological integrity in the Mississippi Alluvial Plain Ecoregion.

6. Physical and chemical variables having correlations greater than $|0.50|$ (Spearman's rho) with site scores of the first detrended correspondence analysis axis of fish and macroinvertebrate communities sampled at 36 sites in the Mississippi Alluvial Plain Ecoregion

7. A comparison of four fish metrics to index of ecological integrity classifications for six sites sampled in the Mississippi Alluvial Plain Ecoregion in 1998

8. Selected water-quality data for six sites in the Mississippi Alluvial Plain Ecoregion belonging to three $a$ priori classifications.

9. Coefficient of variation for four fish metrics measured at two multiple-reach sites in 1996, and at six multiple-year sites from 1996 to 1998

10. Correlations of values calculated with two scoring methods considered for an index of ecological integrity in the Mississippi Alluvial Plain Ecoregion to selected chemical and physical metrics

11. Index of ecological integrity results for 36 sites in the Mississippi Alluvial Plain Ecoregion

12. Correlations for geologic properties and pesticide use rates that were greater than $|0.60|$ (Spearman's rho, $\mathrm{p}>0.001$ ) with an index of ecological integrity established in the Mississippi Alluvial Plain Ecoregion.

13. Correlations for the percentage of Holocene deposits and profenofos use rates in 36 basins to the sum of four biological metrics used in an index of ecological integrity in the Mississippi Alluvial Plain Ecoregion 
CONVERSION FACTORS AND VERTICAL DATUM

\begin{tabular}{rll}
\hline \multicolumn{1}{c}{ Multiply } & \multicolumn{1}{c}{ By } & \multicolumn{1}{c}{ To obtain } \\
\hline centimeter $(\mathrm{cm})$ & 0.3937 & inch (in.) \\
meter $(\mathrm{m})$ & 3.281 & foot $(\mathrm{ft})$ \\
kilometer $(\mathrm{km})$ & 0.6214 & mile $(\mathrm{mi})$ \\
hectare $(\mathrm{ha})$ & 2.471 & acre \\
cubic meter per second $\left(\mathrm{m}^{3}\right)$ & 35.31 & cubic foot per second $\left(\mathrm{ft}^{3} / \mathrm{s}\right)$ \\
gram $(\mathrm{g})$ & 0.03527 & ounce $(\mathrm{oz})$ \\
kilogram $(\mathrm{kg})$ & 2.205 & pound $(\mathrm{lb})$ \\
\hline
\end{tabular}

Degrees Celsius $\left({ }^{\circ} \mathrm{C}\right)$ may be converted to degree Fahrenheit $\left({ }^{\circ} \mathrm{F}\right)$ by using the following equation:

${ }^{\circ} \mathrm{F}=1.8\left({ }^{\circ} \mathrm{C}\right)+32$

Degrees Fahrenheit $\left({ }^{\circ} \mathrm{F}\right)$ may be converted to degree Celsius $\left({ }^{\circ} \mathrm{C}\right)$ by using the following equation:

${ }^{\circ} \mathrm{C}=0.55\left({ }^{\circ} \mathrm{F}-32\right)$

In this report, vertical coordinate information is referenced to the National Geodetic Vertical Datum of 1929 (NGVD of 1929). The horizontal datum used for latitude and longitude was North American Datum of 1927 (NAD 27).

\section{ABBREVIATIONS/ACRONYMS USED IN REPORT}

$\mathrm{CA}$ - correspondence analysis

$\mathrm{cm} / \mathrm{km}$ - centimeter per kilometer

$\mathrm{CV}$ - coefficients of variation

DCA - detrended correspondence analysis

DCAF1 - first detrended correspondence analysis axis of the fish community

DDT - dichlorodiphenyltrichloroethane

GIS - geographical information system

IBI - index of biologic integrity

IEI - index of ecological integrity

MAP - Mississippi Alluvial Plain Ecoregion

MVSP - Multivariate Statistical Package

NAWQA - National Water-Quality Assessment Program

TWINSPAN - Two-Way Indicator Species Analysis

USGS - U.S. Geological Survey 



\section{AN INDEX OF ECOLOGICAL INTEGRITY FOR THE MISSISSIPPI ALLUVIAL PLAIN ECOREGION: INDEX DEVELOPMENT AND RELATIONS TO SELECTED LANDSCAPE VARIABLES}

\author{
By B.G. Justus
}

\section{ABSTRACT}

Macroinvertebrate community, fish community, water-quality, and habitat data collected from 36 sites in the Mississippi Alluvial Plain Ecoregion during $1996-98$ by the U.S. Geological Survey were considered for a multimetric index of ecological integrity. Test metrics were correlated to site scores of a Detrended Correspondence Analysis of the fish community (the biological community that was the most statistically significant for indicating ecological conditions in the ecoregion) and six metrics-four fish metrics, one chemical metric (total ammonia plus organic nitrogen), and one physical metric (turbidity) - having the highest correlations were selected for the index. Index results indicate that sites in the northern half of the study unit (in Arkansas and Missouri) were less degraded than sites in the southern half of the study unit (in Louisiana and Mississippi). Of 148 landscape variables evaluated, the percentage of Holocene deposits and cotton insecticide use rates had the highest correlations to index of ecological integrity results. Sites having the highest (best) index scores had the lowest percentages of Holocene deposits and the lowest cotton insecticide use rates, indicating that factors related to the amount of Holocene deposits and cotton insecticide use rates partially explain differences in ecological conditions throughout the Mississippi Alluvial Plain Ecoregion.

\section{INTRODUCTION}

Biological integrity, or the ability of a stream to support a community of organisms comparable to that of the natural habitat of the region (Frey, 1977), is associated with water quality and has been identified as an objective of the U.S. Clean Water Act (as amended in 1977). In recent decades, the index approach, or the summation of key measures (metrics) of resident biological communities or water-quality properties that are related to the overall stream condition, has become a popular method for assessing both biological integrity (Karr and others, 1986; Hughes and Oberdorff, 1998; Barbour and others, 1999) and water quality (Ott, 1978; Dunnette, 1979; and Cude, 2001).

Barbour and others (1999) define a metric as a characteristic of the biota that changes in some predictable way with increased human influence. Herein, that concept is expanded and the term metric also is used in reference to physical and chemical characteristics that can integrate ecological conditions. Merritt and others (2002) recently combined biological metrics with a water-quality metric (percent dissolved-oxygen saturation) for the purpose of assessing ecological integrity in river oxbows; biological metrics and water-quality metrics have not been combined to produce indices for assessing stream ecological integrity.

No single index (or set of metrics) is applicable to all conditions across all regions (Miller and others, 1988), and existing indices are commonly modified or new indices are established for each ecoregion being investigated. Since Karr (1981) developed the first Index of Biotic Integrity (IBI) using fish, the successes of numerous fish IBIs have been documented in many regions and for several surface-water types (Miller and others, 1988; Davis and Simon, 1995; Hughes and Oberdorff, 1998; and Simon, 1999); likewise, water- 
quality indices also have been modified for many regions in the United States and abroad (Cude, 2001).

Generally, the emphasis on water quality in the Mississippi Alluvial Plain Ecoregion (MAP; Omernik, 1987 ) is less than in other areas of the United States. No States in the MAP have adopted biocriteria for streams, and no large-scale ecological studies have been conducted. Investigations may have been impeded for several reasons: (a) population density in the MAP is low, and MAP streams generally are not sources of drinking water; (b) most MAP streams are turbid and lack aesthetic appeal for primary contact; and (c) although the spatial extent of the MAP is quite large, the area in any one of the six States comprising the MAP (i.e., Louisiana, Mississippi, Arkansas, Tennessee, Missouri, and Kentucky) is much smaller than the total area of each State.

Although indices have been used for assessing streams in adjacent upland ecoregions (Shields and others, 1995; Hlass and others, 1998), no biological or ecological indices have been published for assessing MAP streams. Developing an ecologically relevant and cost effective index for the MAP could be beneficial in at least two ways; (1) an index could facilitate biocriteria development, and (2) an index could be used to identify landscape variables that influence ecological integrity.

One problem related to the use of the index approach for assessing ecological integrity in the MAP, as compared to other areas, is that stream-channel and basin alterations related to crop production have resulted in the loss of reference conditions. Hughes (1995) documents why the condition of reference sites that are used for index development should be (1) relatively unaltered, and (2) have little potential for nonpoint source runoff. By these standards, the MAP would not be considered to have reference streams. Concerning point (1), most of the MAP streams having good water chemistry are dredged ditches (a possible effect of permeable sand substrates and ground-water discharge). Concerning point (2), virtually all MAP streams receive agricultural runoff. Given the level of disturbance in MAP streams, an approach different than the conventional reference-stream approach is needed (Karr and others, 1986; Hughes, 1995; Barbour and others, 1999) to develop an index for this ecoregion.

\section{Purpose and Scope}

The purpose of this report is to identify a combination of cost-effective biological, chemical, and physical metrics as an index of ecological integrity (IEI) for MAP streams, and to examine the relation between IEI scores and selected landscape variables. The term "ecological integrity" is used to describe the index because, in addition to biological metrics, chemical and physical metrics were considered and used.

\section{Ecoregion Description}

The MAP extends $850 \mathrm{~km}$ from Cairo, Illinois, to the Gulf of Mexico, and encompasses more than 13 million hectares (Jim Omernik, U.S. Environmental Protection Agency, written commun., 2001). The climate of the MAP is characterized as warm and humid, with the southern part classified as subtropical and the northern part classified as temperate. Mean annual temperatures range from about $14^{\circ} \mathrm{C}$ in the north to about $18^{\circ} \mathrm{C}$ in the south. Annual precipitation ranges from about $120 \mathrm{~cm}$ in the north to about $140 \mathrm{~cm}$ in the south (U.S. Department of Commerce, 1995). Streams in the MAP have low gradients, and relief is commonly less than $12.5 \mathrm{~cm} / \mathrm{km}$ (Arkansas Department of Pollution Control and Ecology, 1987). On average, over 70 percent of the land in the MAP is used for growing row crops (corn, cotton and soybeans) and small grains (rice and wheat). About 75 percent (or about 6.5 million hectares) of the original forested wetlands in the MAP has been cleared and drained (Nature Conservancy, 1992). Many MAP streams have been hydrologically altered; most stream channels have been dredged and some streams have weirs.

\section{Acknowledgments}

The author gratefully acknowledges all the individuals from U.S. Geological Survey (USGS) and the Mississippi Department of Environmental Quality who collected data for this study. Thanks are extended to Naomi Nakagaki and to Megan Jupin of the USGS for calculating pesticide use rates. Thanks are extended to all reviewers. Robert Hughes (Dynamec) provided valuable insight early in the report process. Thomas Cuffney, Robert Goldstein, and Ian Waite of the USGS provided valuable comments on early drafts and encouraged the comparison of ecological integrity to 
landscape variables. Special thanks are extended to my coworker, James Petersen (USGS), who reviewed the manuscript several times and always "had a minute."

\section{INDEX DEVELOPMENT METHODS}

As part of the National Water-Quality Assessment (NAWQA) Program, the USGS collected biological, chemical, and physical data at six spatially distinct sites within the MAP in Arkansas, Louisiana, Mississippi, and Missouri from 1996 to 1998 (fig. 1, table 1). The index described herein was developed by using those data, as well as biological, chemical, and physical data collected at 30 additional sites sampled in the MAP (including a site in Kentucky and a site Tennessee) in 1997 and 1998.

Prior to analyzing data collected in 1997 and 1998 , the 36 sites sampled in each of the 2 years were subdivided into three a priori classifications: streams (in Arkansas, Missouri, Kentucky, and Tennessee) east of Crowleys Ridge (fig. 2; an erosional remnant consisting of 40- to 50-million-year-old sedimentary rock in the upper Mississippi River Alluvial Plain; U.S. Geological Survey, 2001), streams in Arkansas west and south of Crowleys Ridge, and streams in Louisiana and Mississippi. Barbour and others (1999) suggest that a priori classifications can be tested and confirmed with univariate or multivariate statistical methods, and that such classifications can be beneficial for index development. Observations made by USGS personnel as they collected samples throughout the region were equally important for establishing this classification, as were data from the six sites sampled in 1996.

Observations that distinguished streams east of Crowleys Ridge from streams in the other two a priori classifications were that streams east of Crowleys Ridge generally had less clay turbidity during stable low-flow periods, and the streambeds for the "east" streams generally had a high percentage of sand as opposed to fine depositional material. An observation that distinguished streams in Arkansas west and south of Crowleys Ridge from streams in the other two classifications was that these streams generally were less altered (channelized, straightened, dredged, etc.).

Chemical and biological data from the six sites sampled in 1996 also indicated differences between streams in the three spatial classifications. Compared to the five sites in the two other a priori classifications, one site east of Crowleys Ridge had lower nutrient concentrations (Coupe, 2002) and had more fish taxa (Jus- tus and Caskey, 2000). Compared to sites in Louisiana and Mississippi, the site east of Crowleys Ridge also had fewer pesticides detected in water samples (Coupe, 2000), had lower concentrations of pesticides in water samples (Coupe, 2000), had lower concentrations of dichlorodiphenyltrichloroethane (DDT) in fish tissue samples (Kleiss and others, 2000), and had more macroinvertebrate taxa (Justus, 1998). Compared to sites in Louisiana and Mississippi, sites in Arkansas west and south of Crowleys Ridge generally had lower concentrations of nutrients (Coupe, 2002), lower concentrations of DDT in fish tissue samples (Kleiss and others, 2000), and more taxa identified in fish and macroinvertebrate samples (Justus, 1998).

Two factors were considered prior to selecting the 30 sites sampled in 1997 and 1998. First, sites were chosen to represent a gradient of crop intensity for corn, cotton, and rice-three major crops grown in the MAP. Secondly, sites were selected that provided broad spatial coverage of the MAP. County-level land-use data for 1995 and 1996 were used to determine crop intensities (Arkansas Agricultural Statistics Service, 1996; Kentucky Agricultural Statistics Service, 1996; Louisiana Agricultural Statistics Service, 1996: Mississippi Agricultural Statistics Services 1996; Missouri agricultural Statistics Service, 1996; Tennessee Agricultural Statistics Service, 1995). Photographs and maps showing the sampling locations at each of the sampling sites can be viewed at http://ms.water.usgs. gov/misenawqa/ (accessed January 21, 2003).

Biological aspects of the study involved sampling macoinvertebrate and fish communities and assessing habitat quality. Sampling methods generally were consistent with NAWQA sampling protocols; however, because of environmental conditions specific to the MAP, some biological sampling methods were modified slightly. Detailed biological methods for all study aspects are described in Justus and Caskey (2000) and Justus and others (2000).

Macroinvertebrates were collected from all 36 sites in 1997 by using a D-frame net with a mesh size of $425 \mu \mathrm{m}$. Six habitats were sampled: undercut banks, aquatic vegetation, coarse woody drift, deteriorating leaves, deteriorating sticks, and fine sediment. Fish samples were collected in 1998 by electrofishing and seining the same reach that had been sampled for macroinvertebrates. In conjunction with fish community 


\section{EXPLANATION}

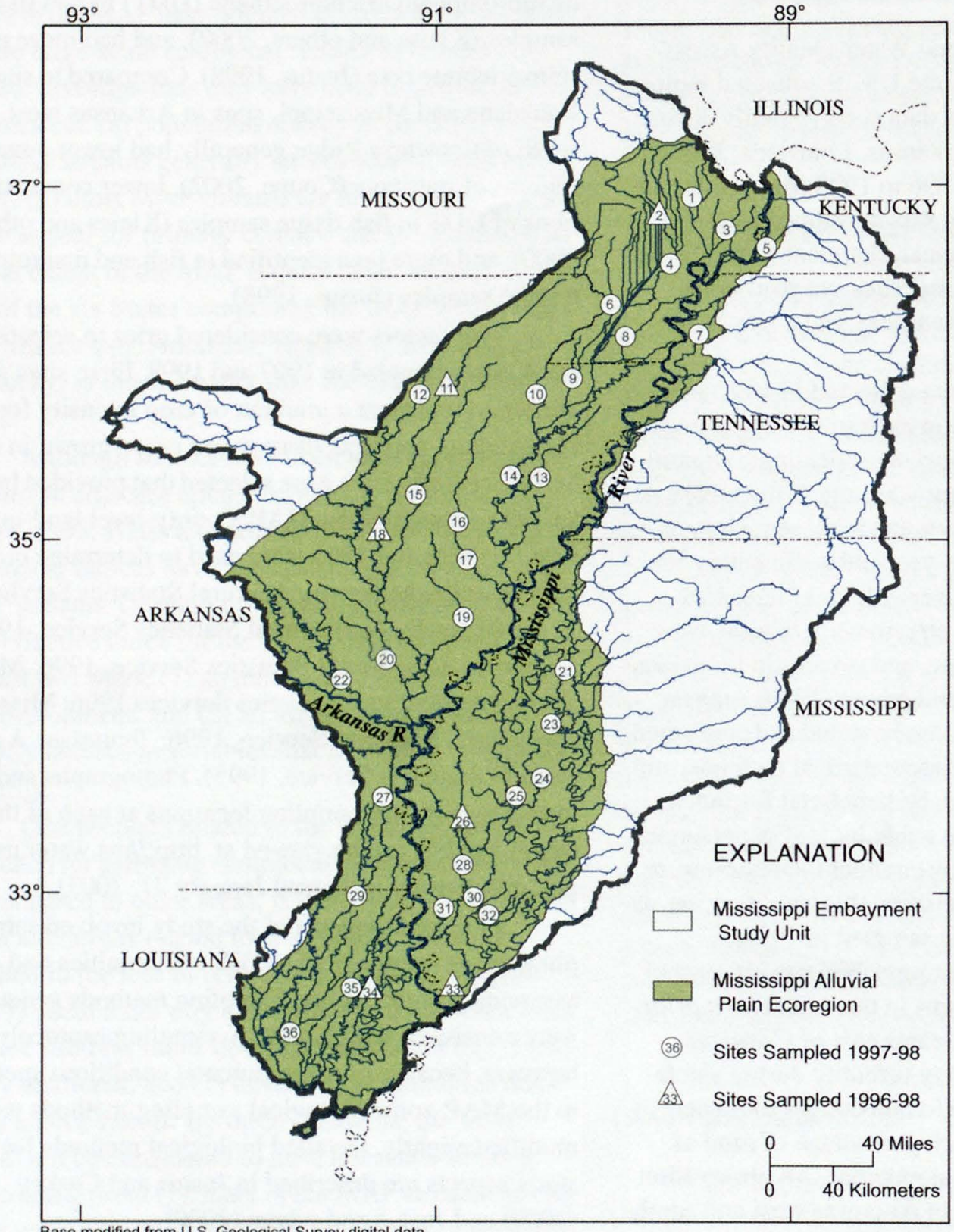

Base modified from U.S. Geological Survey digital data

$1: 2,000,000,1972$

Albers Equal-Area projection

Standard parallels $29^{\circ} 30^{\prime}$ and $45^{\circ} 30^{\prime}$; central meridian
Sampling sites

1. St. Johns Ditch near Sikeston, Mo.

2. Little River Ditch no. 1 near Morehouse, Mo.

3. Spillway Ditch at Hwy 102 near East Prairie,Mo.

4. Little River Ditch no. 251 near Libourn, Mo.

5. Obion Creek near Hickman, Ky.

6. Main Ditch at Hwy 153 near White Oak, Mo.

7. Running Reelfoot at Hwy 103, Tenn.

8. Elk Chute near Gobler, Mo.

9. Cockle Burr Slough Ditch near Monette, Ark

10. St. Francis River at Lake City, Ark.

11. Cache River at Egypt, Ark.

12. Village Creek near Swifton, Ark

13. Tyronza River near Twist, Ark.

14. St. Francis River near Coldwater, Ark

15. Bayou DeView at Morton, Ark.

16. Second Creek near Palestine, Ark.

17. L'Anguille River near Palestine, Ark.

18. Cache River vear Cotton Plant, Ark

19. Big Creek at Popular Grove, Ark.

20. LaGrue Bayou near Dewitt, Ark.

21. Coldwater River at Marks, Miss.

22. Bayou Meto at Bayou Meto, Ark.

23. Cassidy Bayou at Webb, Miss

24. Quiver River near Doddsville, Miss

25. Big Sunflower River at Sunflower, Miss.

26. Bogue Phalia near Leland, Miss.

27. Bayou Macon near Halley, Ark.

28. Deer Creek near Hollandale, Miss.

29. Boeuf River near AR/LA St. Line, Ark.

30. Big Sunflower River near Anguilla, Miss.

31. Steele Bayou East Prong nr Rolling Fork, Miss

32. Silver Creek near Bayland, Miss

33. Yazoo River below Steele Bayou near Long Lake, Miss

34. Tensas River near Tendal, La. 35. Bayou Macon near Delhi, La. 36. Big Creek near Sligo, La.

Figure 1. Location of sites sampled in the Mississippi Alluvial Plain Ecoregion from 1996 to 1998. 
Table 1. Physical information for sampling sites in the Mississippi Alluvial Plain Ecoregion

$\left[\mathrm{km}^{2}\right.$, square kilometers; $\mathrm{m}^{3} / \mathrm{s}$, cubic meters per second; $\mathrm{m}$, meters; $\mathrm{m} / \mathrm{s}$, meters per second; bold denotes sites sampled from 1996 to 1998 . Other sites were sampled in 1997 and 1998 ]

\begin{tabular}{|c|c|c|c|c|c|c|c|c|c|c|}
\hline $\begin{array}{c}\text { Site name } \\
\text { (shown on fig. 1) }\end{array}$ & $\begin{array}{c}\text { Map } \\
\text { number }\end{array}$ & $\begin{array}{l}\text { Station } \\
\text { number }\end{array}$ & Latitude $^{1}$ & Longitude $^{1}$ & $\begin{array}{c}\text { Drainage } \\
\text { basin area } \\
\left(\mathrm{km}^{2}\right)\end{array}$ & $\begin{array}{c}\text { Percent } \\
\text { of basin in } \\
\text { agriculture }^{2}\end{array}$ & $\begin{array}{l}\text { Discharge } \\
\text { at gage } \\
\left(\mathrm{m}^{3} / \mathrm{s}\right)\end{array}$ & $\begin{array}{l}\text { Mean } \\
\text { channel } \\
\text { width } \\
(\mathrm{m})\end{array}$ & $\begin{array}{l}\text { Mean } \\
\text { channel } \\
\text { depth } \\
(m)\end{array}$ & $\begin{array}{c}\text { Mean } \\
\text { instantaneous } \\
\text { velocity } \\
(\mathrm{m} / \mathrm{s})^{4}\end{array}$ \\
\hline St. Johns Ditch near Sikeston, Missouri & 1 & 07043300 & 365608 & 893302 & 101 & 79 & 2.2 & 10.9 & 0.52 & 0.25 \\
\hline Little River Ditch no. 1 near Morehouse, Missouri & 2 & 07043500 & 365003 & 894348 & 1,144 & 61 & 3.0 & 33.7 & 0.35 & 0.13 \\
\hline Spillway Ditch at Hwy 102 near East Prairie, Missouri & 3 & 07024160 & 364454 & 892119 & 186 & 81 & 0.9 & 10.5 & 0.40 & 0.15 \\
\hline Little River Ditch no. 251 near Lilbourn, Missouri & 4 & 07042500 & 363320 & 894012 & 627 & 87 & 3.6 & 22.4 & 0.73 & 0.27 \\
\hline Obion Creek near Hickman, Kentucky & 5 & 07023800 & 363858 & 890721 & 784 & 32 & 1.2 & 12.5 & 0.84 & 0.17 \\
\hline Main Ditch at Hwy 153 near White Oak, Missouri & 6 & 07041120 & 361927 & 900020 & 356 & 88 & 2.2 & 19.9 & 0.33 & 0.36 \\
\hline Running Reelfoot Bayou at Hwy 103, Tennessee & 7 & 07027050 & 360944 & 893036 & 751 & 37 & 0.7 & 13.9 & 0.16 & 0.26 \\
\hline Elk Chute near Gobler, Missouri & 8 & 07046515 & 361018 & 895734 & 218 & 95 & 0.7 & 11.7 & 0.20 & 0.14 \\
\hline Cockle Burr Slough Ditch near Monette, Arkansas & 9 & 07040496 & 355139 & 901949 & 146 & 96 & 3.3 & 53.1 & 1.06 & 0.08 \\
\hline St. Francis River at Lake City, Arkansas & 10 & 07040450 & 354916 & 902556 & 6,150 & 28 & 11.0 & 24.6 & 2.90 & 0.45 \\
\hline Cache River at Egypt, Arkansas & 11 & 07077380 & 355128 & 905600 & 1,816 & 78 & 8.8 & 21.7 & 2.34 & 0.18 \\
\hline Village Creek near Swifton, Arkansas & 12 & 07074660 & 354910 & 910505 & 410 & 92 & 4.7 & 115.8 & 0.74 & 0.11 \\
\hline Tyronza River near Twist, Arkansas & 13 & 07047700 & 352229 & 902805 & 1,367 & 92 & 4.6 & 19.0 & 0.81 & 0.21 \\
\hline St. Francis River near Coldwater, Arkansas & 14 & 07047520 & 352152 & 903436 & 13,774 & 59 & 36.1 & 58.9 & 1.27 & 0.46 \\
\hline Bayou DeView at Morton, Arkansas & 15 & 07077700 & 351507 & 910637 & 1,081 & 73 & 4.6 & 28.8 & 2.62 & 0.06 \\
\hline Second Creek near Palestine, Arkansas & 16 & 07047947 & 350221 & 905440 & 111 & 65 & 2.5 & 15.1 & 0.73 & 0.28 \\
\hline L'Anguille River near Palestine, Arkansas & 17 & 07047950 & 345820 & 905310 & 1,983 & 77 & 8.7 & 24.6 & 2.09 & 0.18 \\
\hline Cache River near Cotton Plant, Arkansas & 18 & 07077555 & 350207 & 911919 & 2,996 & 79 & 14.6 & 35.0 & 2.00 & 0.22 \\
\hline Big Creek at Poplar Grove, Arkansas & 19 & 07077950 & 343320 & 905044 & 1,160 & 77 & 6.3 & 17.8 & 2.21 & 0.23 \\
\hline LaGrue Bayou near Dewitt, Arkansas & 20 & 07078040 & 341900 & 911657 & 594 & 71 & 0.0 & 8.1 & 0.61 & 0.00 \\
\hline Coldwater River at Marks, Mississippi & 21 & 07279950 & 341522 & 901557 & 4,937 & 43 & 90.7 & 37.5 & 4.60 & 0.50 \\
\hline Bayou Meto near Bayou Meto, Arkansas & 22 & 07265099 & 341205 & 913145 & 2,078 & 55 & 0.0 & 25.5 & 3.54 & 0.00 \\
\hline
\end{tabular}


a Table 1. Physical information for sampling sites in the Mississippi Alluvial Plain Ecoregion--Continued

$\left[\mathrm{km}^{2}\right.$, square kilometers; $\mathrm{m}^{3} / \mathrm{s}$, cubic meters per second; $\mathrm{m}$, meters; $\mathrm{m} / \mathrm{s}$, meters per second; bold denotes sites sampled from 1996 to 1998 . Other sites were sampled in 1997 and 1998 ]

\begin{tabular}{|c|c|c|c|c|c|c|c|c|c|c|}
\hline $\begin{array}{c}\text { Site name } \\
\text { (shown on fig. 1) }\end{array}$ & $\begin{array}{c}\text { Map } \\
\text { number }\end{array}$ & $\begin{array}{l}\text { Station } \\
\text { number }\end{array}$ & Latitude $^{1}$ & Longitude ${ }^{1}$ & $\begin{array}{c}\text { Drainage } \\
\text { basin area } \\
\left(\mathrm{km}^{2}\right)\end{array}$ & $\begin{array}{c}\text { Percent } \\
\text { of basin in } \\
\text { agriculture }\end{array}$ & $\begin{array}{l}\text { Discharge } \\
\text { at gage }^{3} \\
\left(\mathrm{~m}^{3} / \mathrm{s}\right)\end{array}$ & $\begin{array}{l}\text { Mean } \\
\text { channel } \\
\text { width } \\
(\mathrm{m})\end{array}$ & $\begin{array}{l}\text { Mean } \\
\text { channel } \\
\text { depth } \\
\text { (m) }\end{array}$ & $\begin{array}{c}\text { Mean } \\
\text { instantaneous } \\
\text { velocity } \\
(\mathrm{m} / \mathrm{s})^{4}\end{array}$ \\
\hline Cassidy Bayou at Webb, Mississippi & 23 & 07280900 & 335659 & 902028 & 536 & 85 & 2.4 & 62.2 & 0.85 & 0.04 \\
\hline Quiver River near Doddsville, Mississippi & 24 & 07288570 & 333825 & 902405 & 651 & 81 & 5.8 & 16.3 & 1.65 & 0.24 \\
\hline Big Sunflower River at Sunflower, Mississippi & 25 & 07288500 & 333250 & 903235 & 2,010 & 81 & 15.0 & 23.2 & 2.19 & 0.56 \\
\hline Bogue Phalia near Leland, Mississippi & 26 & 07288650 & 332347 & 905047 & 1,301 & 80 & 5.3 & 37.7 & 1.34 & 0.09 \\
\hline Bayou Macon near Halley, Arkansas & 27 & 0736765950 & 333216 & 911736 & 376 & 85 & 9.8 & 14.6 & 1.20 & 0.45 \\
\hline Deer Creek near Hollandale, Mississippi & 28 & 07288770 & 330859 & 905047 & 231 & 81 & 0.0 & 19.2 & 1.71 & 0.00 \\
\hline Boeuf River near Arkansas/Louisiana State Line, Louisiana & 29 & 07367700 & 325825 & 912625 & 1,822 & 83 & 6.2 & 45.0 & 2.32 & 0.07 \\
\hline Big Sunflower River near Anguilla, Mississippi & 30 & 07288700 & 325818 & 904640 & 6,675 & 78 & 46.0 & 89.8 & 3.98 & 0.15 \\
\hline Steele Bayou East Prong near Rolling Fork, Mississippi & 31 & 07288870 & 325441 & 905710 & 1,122 & 81 & 2.9 & 49.6 & 2.02 & 0.08 \\
\hline Silver Creek near Bayland, Mississippi & 32 & 0728872008 & 325208 & 904145 & 47.9 & 56 & 0.0 & 20.4 & 0.13 & 0.00 \\
\hline Yazoo River below Steele Bayou near Long Lake, Mississippi & 33 & 07288955 & 322640 & 905400 & 34,850 & 41 & 405.0 & 91.4 & 5.92 & 0.49 \\
\hline Tensas River at Tendal, Louisiana & 34 & 07369500 & 322555 & 912200 & 721 & 74 & 2.4 & 19.3 & 1.26 & 0.26 \\
\hline Bayou Macon near Delhi, Louisiana & 35 & 07370000 & 322725 & 912830 & 2,141 & 78 & 6.8 & 55.4 & 2.02 & 0.08 \\
\hline Big Creek near Sligo, Louisiana & 36 & 07368580 & 321220 & 914911 & 1,311 & 76 & 1.6 & 48.4 & 1.75 & 0.02 \\
\hline
\end{tabular}

${ }^{1}$ The horizontal datum used for latitude and longitude was North American Datum of 1927 (NAD 27).

${ }^{2}$ Includes all areas used for the production of row crops such as soybeans, vegetables, tobacco, and cotton, as well as small grains such as wheat and rice. Excludes areas used for the production of hay and pasture.

${ }^{3}$ Discharge was measured during one stable low-flow period in 1997.

${ }^{4}$ Velocity was measured during one stable low-flow period in 1997 


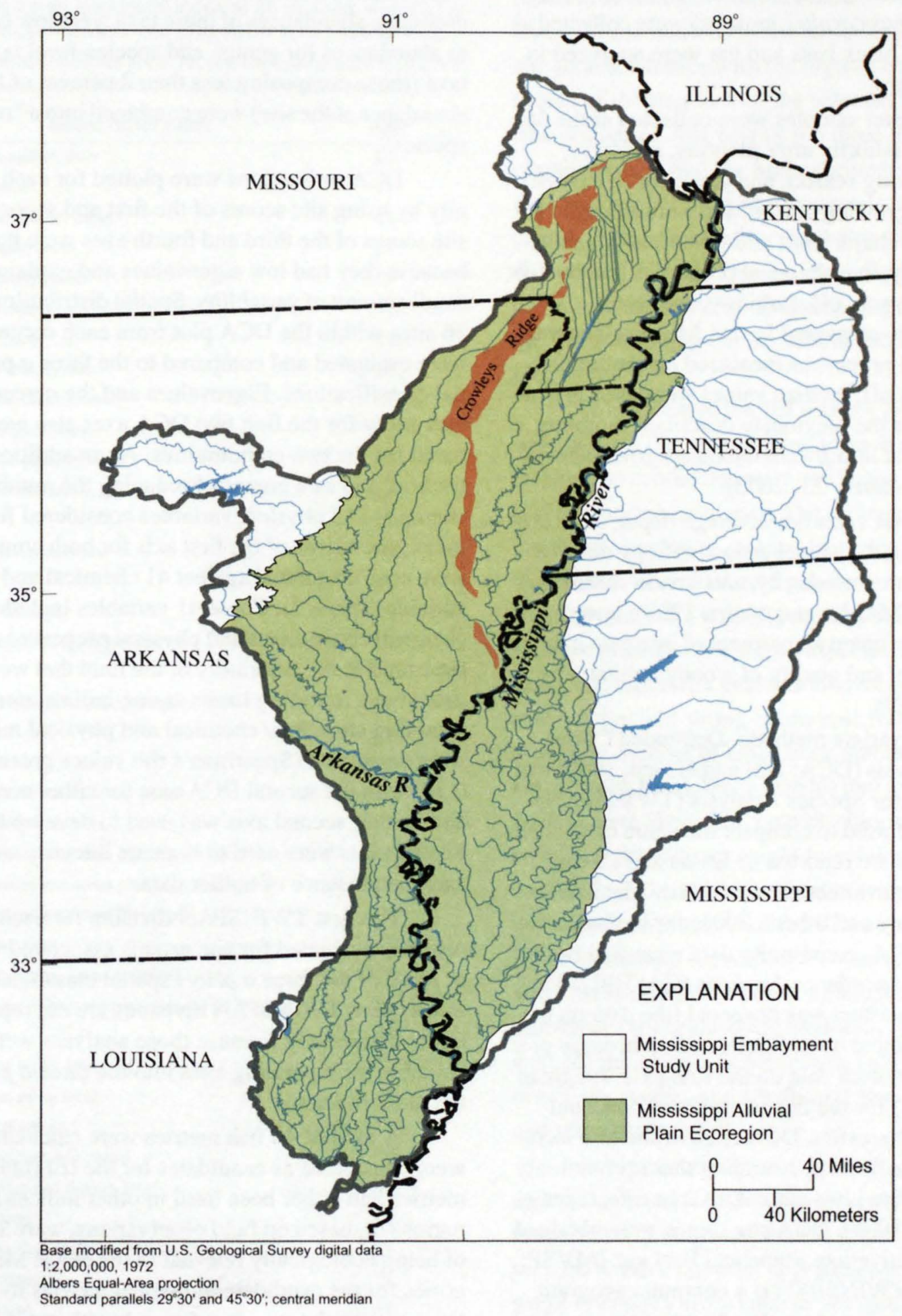

Figure 2. Mississippi Embayment Study Unit showing Crowleys Ridge and part of the Mississippi Alluvial Plain Ecoregion. 
sampling, field personnel also collected fish tissue samples for organochlorine pesticide analysis. Common carp (Cyprinus carpio Linnaeus) were collected at all but two sites; black bass and gar were analyzed in the absence of carp.

Surface-water samples were collected at the 36 sites three times (shortly after planting, midway through the growing season, and just prior to harvest) during the 1997 growing season, and were analyzed for 23 pesticides, 10 major ions, and 8 nutrient constituents. Additionally, five chemical properties (conductivity, dissolved oxygen, $\mathrm{pH}$, turbidity, and water temperature) were measured in situ. Mean values were calculated for all properties measured on multiple occasions except $\mathrm{pH}$; median values were used to evaluate $\mathrm{pH}$. Data for the previously described sampling can be accessed at http://waterdata.usgs.gov/ms/nwis/ nwis (accessed January 21, 2003).

Eight habitat variables (average depth, bank stability, canopy angle, channel aspect, canopy density, channel width, stream velocity, and stream discharge) were measured (Meador and others, 1993); however, clay turbidity prevented assessment of instream habitat features (quantity and quality of woody habitats) by NAWQA protocols.

Two multivariate methods-Detrended Correspondence Analysis (DCA; Hill'and Gauch, 1980) and Two-Way Indicator Species Analysis (TWINSPAN; Hill, 1979)-were used to compare the value of the fish community (data are reported in Justus and Caskey, 2000) and macroinvertebrate community (data are reported in Caskey and others, 2001) for the index. Prior to using DCA, community data were first ordinated with Correspondence Analysis (CA; Hill, 1974); however, an arch effect was observed (the data on the second axis exhibited no new information because of a quadratic relation with data on the first axis; Jongman and others, 1995) for the fish community data, and DCA was used thereafter. DCA is an ordination technique based on reciprocal averaging that is commonly used when CA data plots exhibit an arch effect (Jongman and others, 1995). DCA site scores were obtained by using the Multivariate Statistical Package (MVSP; Kovach, 1998). TWINSPAN is a computer program that separates sites based on abundance of species, and allows the construction of an ordered two-way table that expresses the synecological relations of the species (Hill, 1979). TWINSPAN results were obtained by using the Cornell Ecology Program (Hill, 1979) set for default values. The same data sets were used for both
DCA and TWINSPAN. Family-level taxa and higher were omitted from the analysis because, in almost all cases, the abundances of these taxa were low compared to abundances for genus- and species-level taxa. Rare taxa (those composing less than 2 percent of the total abundance at the site) were combined into a "rare-taxa" species.

DCA ordinations were plotted for each community by using site scores of the first and second axes; site scores of the third and fourth axes were not plotted because they had low eigenvalues and explained a small amount of variability. Spatial distributions for the 36 sites within the DCA plot from each community were evaluated and compared to the three a priori spatial classifications. Eigenvalues and the percentage of variability for the first two DCA axes also were compared for the two communities. As an additional comparison, and as a means of reducing the number of chemical and physical variables considered for the index, site scores of the first axis for both communities were each correlated against 41 chemical and physical variables (table 2 ). These 41 variables included all chemical constituents and physical properties that were measured in the laboratory or the field that were detectable above reporting limits at one-half or more of the sampling sites. Few chemical and physical metrics were correlated (Spearman's rho values greater than 0.50 ) with the second DCA axis for either community, and neither second axis was used to develop the IEI. Scatter plots were used to evaluate linearity and to indicate the presence of outlier data.

The first TWINSPAN division for each community was evaluated for site groups associated with one or more of the three a priori spatial classifications. Subsequent TWINSPAN divisions are not reported for either community because those analyses were not valuable for separating sites into the three a priori spatial classifications.

A total of 43 fish metrics were calculated and were considered as candidates for the IEI (table 3). All metrics had either been used in other indices for other regions or, based on field observations, were suspected of being ecologically relevant in the MAP. Metric categories for the candidate biological metrics included taxonomic richness, abundance, health, trophic guilds and feeding processes, diversity, and tolerance. The 41 chemical and physical metrics that were detectable above reporting limits at one-half or more of the sampling sites also were considered as candidates for the IEI (table 2). 
Table 2. Chemical and physical metrics considered as candidates for an ecological index at 36 streams sampled in the Mississippi Alluvial Plain Ecoregion from 1995 to 1998

[CL, chemical determination in lab; PF, physical determination in field; $\mathrm{CF}$, chemical determination in field; PL, physical determination in lab]

\begin{tabular}{|c|c|}
\hline Metric description & Type \\
\hline 3,4-dichloraniline, sum & $\mathrm{CL}$ \\
\hline Atrazine, sum & $\mathrm{CL}$ \\
\hline Calcium carbonate, mean & $\mathrm{CL}$ \\
\hline Canopy angle, mean & PF \\
\hline Canopy density, mean & PF \\
\hline Channel width, mean & PF \\
\hline Cyanazine, sum & $\mathrm{CL}$ \\
\hline Cyanazine-amide, sum & $\mathrm{CL}$ \\
\hline DDT (in fish tissue), total & $\mathrm{CL}$ \\
\hline Deethyl-atrazine, sum & CL \\
\hline Deisopropyl-atrazine, sum & $\mathrm{CL}$ \\
\hline Demethyl-norflurazon, sum & $\mathrm{CL}$ \\
\hline Discharge & PF \\
\hline Dissolved oxygen, mean & $\mathrm{CF}$ \\
\hline Elevation & PL \\
\hline Fluometuron, sum & $\mathrm{CL}$ \\
\hline Herbicide detects, mean number of & CL \\
\hline Latitude & PL \\
\hline Macroinvertebrate habitat quality, estimated & $\mathrm{PF}$ \\
\hline Metalochlor, sum & CL \\
\hline Molinate, sum & $\mathrm{CL}$ \\
\hline Nitrate plus nitrite, mean dissolved & $\mathrm{CL}$ \\
\hline Nitrite, mean dissolved & $\mathrm{CL}$ \\
\hline Nitrogen, mean ammonia plus organic total & $\mathrm{CL}$ \\
\hline Nitrogen, mean ammonia plus organic dissolved & $\mathrm{CL}$ \\
\hline Nitrogen, mean ammonia dissolved & $\mathrm{CL}$ \\
\hline Norflurazon, sum & $\mathrm{CL}$ \\
\hline Ortho-phosphorus, mean dissolved & $\mathrm{CL}$ \\
\hline Sand, percent in bed-sediment sample & PL \\
\hline $\mathrm{pH}$, median & $\mathrm{CF}$ \\
\hline Phosphorus, mean dissolved & $\mathrm{CL}$ \\
\hline Phosphorus, mean total & CL \\
\hline Secchi depth, mean & PF \\
\hline Specific conductance, mean & $\mathrm{PF}$ \\
\hline Toxaphene (in fish tissue), total & $\mathrm{CL}$ \\
\hline Triazines, total & $\mathrm{CL}$ \\
\hline Trifluoro-methyl-aniline (TFMA), sum & $\mathrm{CL}$ \\
\hline Turbidity, mean & PL \\
\hline Velocity, mean & PF \\
\hline Water depth, mean & PF \\
\hline Water temperature, mean & PF \\
\hline
\end{tabular}

Biological, chemical, and physical metrics were retained or omitted from consideration for the index based on correlations between each metric and DCA site scores. Metrics with the highest correlations to site scores of the first axis of the selected DCA ordination (the ordination that best fit the three a priori spatial classifications, had the highest eigenvalues, explained the most variability, and was correlated to the most chemical and physical metrics) were retained as candidates for the index. These metrics were suspected of having strong relations to underlying factors responsible for positioning the 36 sites in the DCA ordination plot.

To ensure that the IEI was not influenced by multiple metrics that were related to each other, all metrics retained as candidates were evaluated for redundancy and taxonomic similarity. The redundancy evaluation involved correlating metrics in each respective group (biological, chemcial, and physical) with one another. Metrics that had a 0.80 (Spearman's rho) or higher correlation to each other were suspected of being redundant. The similarity evaluation involved identifying metrics that had strong taxonomic relations to each other (the number of black bass, and the sum of lengths for all black bass). Once metrics that were redundant or similar were identified, considerations that determined which of the metrics would be retained for the IEI included (a) the strength of the correlations of each metric with site scores of the first axis of the selected DCA ordination, (b) response consistency to other variables measured at the site (an indication of ecological relevance), (c) costs associated with sampling or analysis, (d) the amount of subjective judgment required to obtain the metric, and (e) diurnal variability (chemical and physical metrics).

Response consistency for each of the biological metrics selected for the index to other variables was evaluated by comparing metric scores at two sites that seemed to have the least degraded and most degraded water chemistry from each of the three a priori classifications. In theory, sites having the least degraded water chemistry would be expected to have favorable biological metric scores, whereas sites with the most degraded water chemistry would be expected to have less favorable biological metric scores. 
Table 3. Fish metrics considered as candidates for an index of ecological integrity in the Mississippi Alluvial Plain Ecoregion [Correlations for metrics and site scores of the first detrended correspondence analysis (DCA) axis of the fish community that were greater than 10.501 are given; R, Spearman's rho value; >, greater than; LC - correlation was less than 10.501 ; bold denotes metric selected for the index; NA - not applicable; all correlations with $R>10.501$ had $\mathrm{p}<0.001]$

\begin{tabular}{|c|c|c|c|}
\hline Metric description & $\begin{array}{l}\text { Metric } \\
\text { number }\end{array}$ & $\begin{array}{c}\text { Metrics with } \\
R>0.50 \text { to } \\
\text { DCA site scores }\end{array}$ & $\begin{array}{c}\text { Reason metric not } \\
\text { selected }\end{array}$ \\
\hline Abundance & 1 & - & LC \\
\hline Average standard length of all individuals & 2 & - & LC \\
\hline Average standard length of black bass & 3 & 0.60 & redundant; $R>0.80$ with metric 40 \\
\hline Average standard length of bluegill & 4 & 0.50 & taxonomically similar to metric 5 \\
\hline Average standard length of all Lepomis & 5 & 0.71 & NA \\
\hline Biomass & 6 & - & $\mathrm{LC}$ \\
\hline Brillouin diversity/Brillouin evenness & 7 & - & LC \\
\hline Brillouin evenness & 8 & - & LC \\
\hline Brillouin diversity & 9 & - & LC \\
\hline Number of benthic taxa & 10 & 0.59 & taxonomically similar to metric 13 \\
\hline Number of black bass & 11 & 0.75 & redundant; $R>0.80$ with metric 40 \\
\hline Number of fish taxa & 12 & - & $\mathrm{LC}$ \\
\hline Number of insectivore taxa & 13 & 0.63 & NA \\
\hline Number of intolerants taxa & 14 & 0.58 & redundant; $R>0.80$ with metric 13 \\
\hline Number of madtom, darter, minnow, and sucker taxa & 15 & - & $\mathrm{LC}$ \\
\hline Number of minnow taxa & 16 & - & $\mathrm{LC}$ \\
\hline Number of sunfish taxa & 17 & 0.59 & taxonomically similar to metric 35 \\
\hline Number of tolerant taxa & 18 & - & $\mathrm{LC}$ \\
\hline Percent of buffalo & 19 & - & LC \\
\hline Percent contribution of dominant taxa & 20 & - & LC \\
\hline Percent of common carp & 21 & - & LC \\
\hline Percent of black and white crappie & 22 & - & LC \\
\hline Percent of fish with anomalies & 23 & - & LC \\
\hline Percent of sunfish that are green sunfish and orangespotted sunfish & 24 & - & LC \\
\hline Percent of gizzard and threadfin shad & 25 & - & LC \\
\hline Percent of western mosquitofish & 26 & - & LC \\
\hline Ratio tolerant/intolerant taxa & 27 & -0.61 & redundant; $\mathrm{R}>0.80$ with metric 13 \\
\hline Relative abundance of Centrarchids & 28 & 0.74 & taxonomically similar to metric 5,35 , and 40 \\
\hline Relative abundance of exotics & 29 & - & $\mathrm{LC}$ \\
\hline Relative abundance of fish with anomalies & 30 & - & LC \\
\hline Relative abundance of gar & 31 & - & LC \\
\hline Relative abundance of insectivores & 32 & - & LC \\
\hline Relative abundance of sunfish & 33 & - & LC \\
\hline Relative abundance of omnivores & 34 & - & LC \\
\hline Relative abundance of green sunfish and orangespotted sunfish & 35 & -0.62 & NA \\
\hline Relative abundance of top carnivores & 36 & - & LC \\
\hline Shannon diversity & 39 & - & LC \\
\hline Shannon diversity/Shannon evenness & 37 & - & LC \\
\hline Shannon evenness & 38 & - & LC \\
\hline Sum of lengths for all black bass & 40 & 0.79 & NA \\
\hline Sum of lengths for all bluegill & 41 & - & LC \\
\hline Sum of lengths for all green sunfish & 42 & - & LC \\
\hline Sum of lengths for all orangespotted sunfish & 43 & - & LC \\
\hline
\end{tabular}


Biological samples collected from three reaches at each of two sites sampled in 1996 and from six sites in each of 3 years from 1996 to 1998 were used to calculate coefficients of spatial variation and coefficients of temporal variation. Coefficients of variation (CV) for the spatial and temporal components were reported as averages for each biological metric selected for the IEI.

Two methods were evaluated for scoring index metrics - a "centering" method (Minns and others, 1994; Hughes and others, 1998; and Ganasan and Hughes, 1998) and a "ranking" method (Merritt and others, 2002). The underlying assumptions of both scoring methods are that the ecological integrity for the sites sampled covers the range of ecological integrity in the study area, and the metrics being used are ecologically relevant.

The centering method uses two approaches to score metrics, depending if high or low metric values indicate least degraded conditions. For metrics where high metric scores indicated least degraded conditions, the metric score was divided by the range of metric values, and the resulting quotient was multiplied by 10 . For example, the range of fish taxa collected at the sites was 37 , therefore, a site with 16 taxa scored 4.3 or [(16/ $37) \times 10]$. For metrics where low metric scores indicated least degraded conditions, the metric score was divided by the range of metric values, but the resulting quotient was subtracted from 1 before being multiplied by 10 . For example, the range of turbidity at the sites was 134.6 nephelometric turbidity units; therefore, a turbidity of 3.4 nephelometric turbidity units was scored as 9.7 or $([1-(3.4 / 134.6) \times 10])$. To produce an IEI ranging from 0 to 100 , centered scores of the six metrics were summed, multiplied by 10 and divided by the number of metrics in the index (Ganasan and Hughes, 1998). Sites having the highest scores had the least degraded conditions, whereas sites with the lowest scores had the most degraded conditions.

For the ranking method, each site was ranked from best (1) to worst (36) based on metric values at the 36 sites. In cases where values for a metric were the same at two sites, both sites were given the same rank and the subsequent rank was used for the next lower or higher value. Ranks for all metrics were summed for each site to get the final site score. Results for the ranking method were converse to results for the centering method; lowest scores indicated least degraded conditions.
As a means of comparing the two scoring methods, results for each method were correlated to chemical and physical metrics that had high correlations to DCA axis scores. The scoring method that had the highest correlations to those chemical and physical metrics was selected for the IEI.

\section{METHODS FOR RELATING THE IEI TO LANDSCAPE VARIABLES}

Index scores were compared to 148 landscape variables (tables 4 and 5). Landscape variables included use rates (kilogram of an active ingredient applied per basin) for 91 pesticides that are used on corn, cotton, and rice in the MAP (Gianessi and Anderson, 1995); 32 estimated and reported fertilizer rates (Battaglin and Goolsby, 1995); percentage of three surficial geologic formations (Saucier, 1994); population (U.S. Department of Commerce, Bureau of Census, 1990); and 21 other land-use/land-cover, soils, and riparian habitat characteristics identified with geographical information systems (GIS). The 21 variables were identified as part of a cooperative project between the USGS and the U.S. Environmental Protection Agency. Data for the GIS coverage were obtained from remote sensing data (Vogelman and others, 1998) and from Natural Resource Conservation Service soils data (U.S. Department of Agriculture, 1991). Data for the 148 landscape variable also can be accessed at the following USGS web site using station numbers listed in table 1: http://wwwdcascr.wr.usgs.gov/pnsp/gis/data/ swancil (accessed January 21, 2003).

Basin-level pesticide-use rates for the 91 pesticides and three crops were estimated as part of the NAWQA Pesticide National Synthesis Project using State-based pesticide use coefficients compiled over a 5-year period (1990-1993 and 1995; Gianessi and Anderson, 1995) along with State and Federal cropacreage data obtained from the 1992 Census of Agriculture website, http://www.census.gov/prod/2/agr/ 92area/92agr.html (accessed January 21, 2003). To obtain estimates for basin-level pesticide-use rates, county-level pesticide-use rates were obtained by multiplying State-based pesticide-use coefficients by county-level crop acreages (Thelin and Gianessi, 2000). Secondly, county-level pesticide-use rates were multiplied by the area of each county in each respective 
Table 4. Pesticides for which use rates were evaluated as land-use variables in the Mississippi Alluvial Plain Ecoregion [Data from 1990-93 and 1995 were used to estimate pesticide use (Gianessi and Anderson, 1995). Soy, soybeans; Cot, cotton; Misc, miscellaneous; I, insecticide; $\mathrm{H}$, herbicide; F, fungicide; $\mathrm{D}$, defoliant]

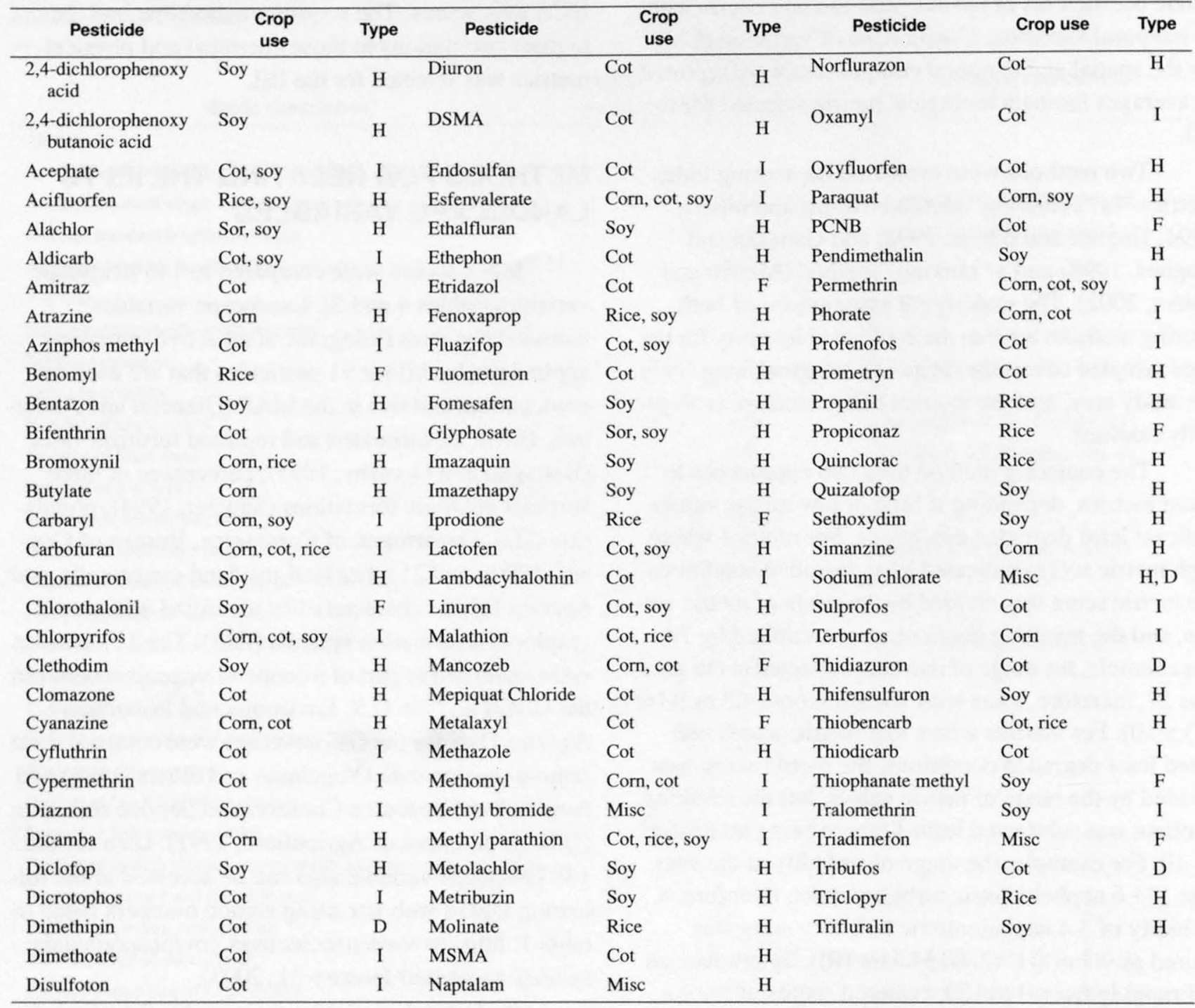


Table 5. Land-use variables (other than pesticide use rates) that were compared to an index of ecological integrity in the Mississippi Alluvial Plain Ecoregion

\section{Estimated Fertilizer Use Rates}

Kilograms of nitrogen in all fertilizers estimated per year

Kilograms of phosphorus in all fertilizers estimated per year

Kilograms of potassium in all fertilizers estimated per year

Kilograms of nitrogen as ammonium nitrate estimated per year

Kilograms of nitrogen as anhydrous ammonia estimated per year

Kilograms of nitrogen in other forms-miscellaneous estimated per year

Kilograms of nitrogen in liquid/solution estimated per year

Kilograms of nitrogen in urea estimated per year

Kilograms of nitrogen in all fertilizers estimated for fall

Kilograms of phosphorus in all fertilizers estimated for fall

Kilograms of potassium in all fertilizers estimated for fall

Kilograms of nitrogen as ammonium nitrate estimated for fall

Kilograms of nitrogen as anhydrous ammonia estimated for fall

Kilograms of nitrogen in other forms-miscellaneous estimated for fall

Kilograms of nitrogen in liquid/solution estimated for fall

Kilograms of nitrogen in urea estimated for fall

\section{Reported Fertilizer Use Rates}

Kilograms of nitrogen in all fertilizers reported per year

Kilograms of phosphorus in all fertilizers reported per year

Kilograms of potassium in all fertilizers reported per year

Kilograms of nitrogen as ammonium nitrate reported per year

Kilograms of nitrogen as anhydrous ammonia reported per year

Kilograms of nitrogen in other forms-miscellaneous reported per year

Kilograms of nitrogen in liquid/solution reported per year

Kilograms of nitrogen in urea reported per year

Kilograms of nitrogen in all fertilizers reported for fall

Kilograms of phosphorus in all fertilizers reported for year

Kilograms of potassium in all fertilizers reported for fall

Kilograms of nitrogen as ammonium nitrate reported for fall

Kilograms of nitrogen as anhydrous ammonia reported for fall

Kilograms of nitrogen in other forms-miscellaneous reported for fall

Kilograms of nitrogen in liquid/solution reported for fall

Kilograms of nitrogen in urea reported for fall

\section{Surficial Geology}

Percentage of Holocene deposits in the basin

Percentage of Pleistocene deposits in the basin

Percentage of Tertiary deposits in the basin

\section{National land cover data}

Percent open water

Percent total forest

Percent forest plus woody wetlands

Percent total agriculture

Percent agriculture minus pasture/hay

\section{Soil}

Average permeability of basin soils

Percent of basin poorly drained

\section{Crops}

Corn hectares in basin

Corn cubic meters in basin

Cotton hectares in basin

Cotton bales in basin

Oats hectares in basin

Oats cubic meters in basin

Rice hectares in basin

Rice cubic meters in basin

Sorghum hectares in basin

Sorghum cubic meters in basin

Soybean hectares in basin

Soybeans cubic meters in basin

Wheat hectares in basin

Wheat cubic meters in basin

\section{General}

Population 
stream basin, and all products for all counties in the basin were summed.

\section{RESULTS FOR INDEX DEVELOPMENT PROCESSES}

Macroinvertebrate metrics were not considered for the IEI because DCA and TWINSPAN results for macroinvertebrate and fish community samples indicated the fish community was more valuable than the macroinvertebrate community for the IEI. The three $a$ priori, spatial classifications - sites in Arkansas, Missouri, Kentucky, and Tennessee east of Crowleys Ridge, sites in Arkansas west and south of Crowleys Ridge, and sites in Louisiana and Mississippi-were relatively distinct in the plot for the DCA ordination of the fish community (fig. 3), but broadly overlapped in the plot for the DCA ordination of the macroinvertebrate community (fig. 4). Eigenvalues for the DCA of the fish community (first axis $=0.59$ ) were higher than eigenvalues for the DCA of the macroinvertebrate community (first axes $=0.46$ ), and the variance explained by the first two axes of the DCA of the fish community (23.4 percent) was higher than the amount of variance explained by the first two axes of the DCA of the macroinvertebrate community (18.1 percent). Additionally, site scores for the first DCA axis of the fish community (DCAF1 site scores) were correlated to more chemical and physical metrics, and generally had higher correlations to the chemical and physical metrics than did site scores of the first DCA axis of the macroinvertebrate community (table 6).

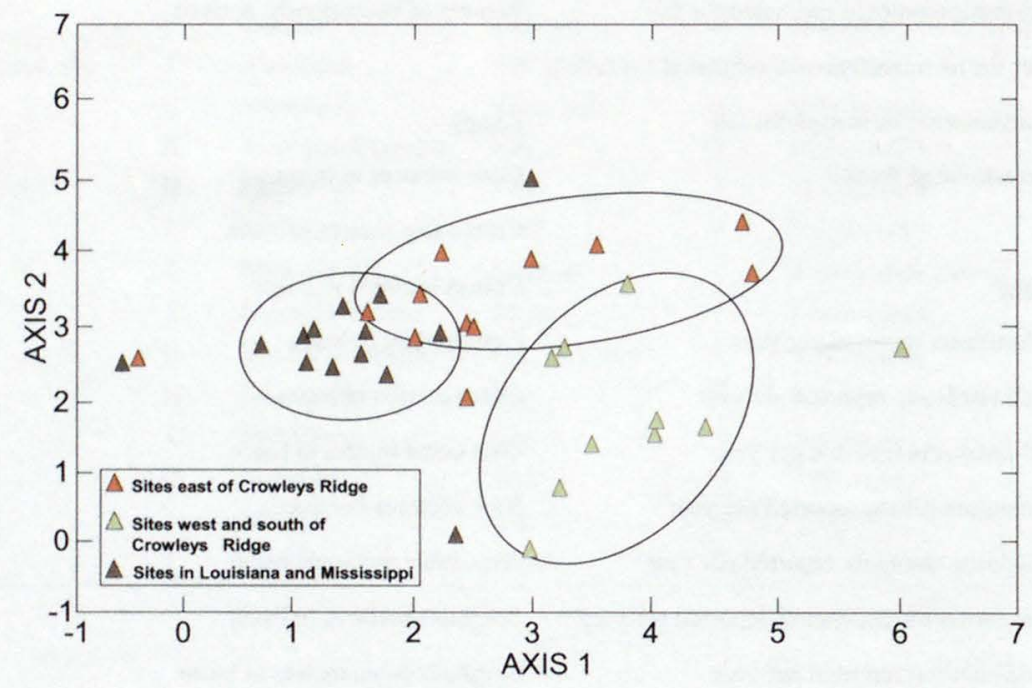

Figure 3. Detrended correspondence analysis ordination plot of site scores on the first two axes for fish community samples collected at 36 sites in the Mississippi Alluvial Plain Ecoregion. 


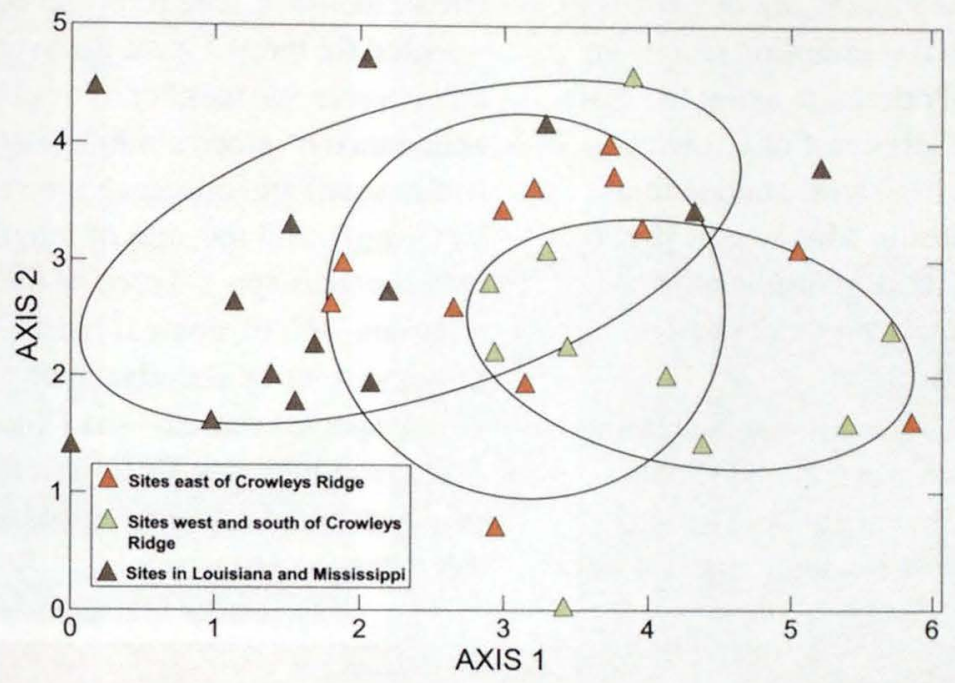

Figure 4. Detrended correspondence analysis ordination plot of site scores on the first two axes for macroinvertebrate community samples collected at 36 sites in the Mississippi Alluvial Plain Ecoregion.

Table 6. Physical and chemical variables having correlations greater than $|0.50|$ (Spearman's rho) with site scores of the first detrended correspondence analysis (DCA) axis of fish and macroinvertebrate communities sampled at 36 sites in the Mississippi Alluvial Plain Ecoregion

[MI, macroinvertebrate; all correlations to the DCA sites scores of the fish community had p values $<0.01$; the lowest correlations to the DCA site scores of the macroinvertebrate community had a $>0.05$; shaded cells contained the highest rho value; bold denotes metric selected for the index; NA, not applicable]

\begin{tabular}{lcccl}
\hline \multicolumn{1}{c}{ Metric } & $\begin{array}{c}\text { Metric } \\
\text { number }\end{array}$ & Fish & MI & Reason metric not selected for the index \\
\hline DDT (in fish tissue), total & 1 & -0.69 & -0.57 & High cost of analysis \\
Elevation & 2 & 0.67 & 0.63 & Lack of ecological relevance ${ }^{1}$ \\
Fluometuron, sum & 3 & -0.52 & -0.61 & High cost of analysis \\
Latitude & 4 & 0.61 & 0.68 & Lack of ecological relevance ${ }^{2}$ \\
Macroinvertebrate habitat quality, estimated & 5 & 0.56 & 0.61 & Subjective judgement, user inconsistency \\
Number of herbicides detected, mean & 6 & -0.65 & -0.58 & High cost of analysis \\
Nitrate plus nitrite, mean dissolved & 7 & -0.65 & -0.28 & Related to metric 10 \\
Nitrite, mean dissolved & 8 & -0.60 & -0.40 & Related to metric 10 \\
Nitrogen, mean ammonia plus organic dissolved & 9 & -0.54 & -0.52 & Related to metric 10 \\
Nitrogen, mean ammonia plus organic total & 10 & $-\mathbf{0 . 6 5}$ & -0.61 & NA \\
Nitrogen, mean ammonia dissolved & 11 & -0.50 & -0.47 & Related to metric 10 \\
Phosphorus, mean total & 12 & -0.57 & -0.37 & Related to metric 10 \\
Toxaphene (in fish tissue), total & 13 & -0.63 & -0.41 & High cost of analysis \\
Turbidity, mean & 14 & $-\mathbf{0 . 6 8}$ & -0.32 & NA \\
Water temperature, mean & 15 & -0.53 & -0.47 & Diurnal variability \\
\hline
\end{tabular}

${ }^{1}$ The range of elevation for the 36 sites is only 82 meters and ecological differences would not be expected across such a slight gradient.

${ }^{2}$ Although latitude was related to variables considered to be directly related to ecological integrity in the MAP (such as pesticide use, water temperature, and turbidity), latitude was not considered to have a direct relation to ecological integrity.

${ }^{3}$ Water temperature was not sampled at the same time on every day or at every site. 
The first TWINSPAN division using the fish community data separated eight sites east of Crowleys Ridge and two sites in Arkansas west and south of Crowleys Ridge from the 26 remaining sites (fig. 5). The two sites in Arkansas west and south of Crowleys Ridge were unchannelized at the sampling reach. In contrast, the first TWINSPAN division using the macroinvertebrate clustered nine sites east of Crowleys Ridge with five sites in Arkansas west and south of Crowleys Ridge and three sites in Mississippi (fig. 6). Eigenvalues for the first TWINSPAN division were comparable for the fish and macroinvertebrate communities ( 0.30 and 0.35 , respectively).

Of the 43 fish metrics, 12 metrics were retained as candidates because they were correlated (Spearman's rho $>0.50$ and $\mathrm{p}<0.001$ ) with DCAF1 site scores (table 2). Of those 12 metrics, eight metrics were disregarded because they were redundant or taxonomically similar to other fish metrics that had either higher correlations with the DCAF1 site scores, more ecological relevance, or were less difficult or costly to calculate or measure. The four fish community metrics selected for the IEI were the average standard length of all Lepomis, the number of insectivore taxa, the relative abundance of green sunfish (Lepomis cyanellus Rafinesque) and orangespotted sunfish (Lepomis humilis Girard), and the sum of lengths for all black bass (Micropterus spp.). Three of the metrics had positive relations with ecological integrity; however, one metric - the relative abundance of green sunfish and orangespotted sunfish - had an inverse relation with ecological integrity. Collectively, the four metrics measure aspects of relative abundance, trophic guilds, and tolerance (to disturbance).

\begin{tabular}{l}
\hline St. Johns Ditch near Sikeston, MO \\
Little River Ditch no. 1 near Morehouse, MO \\
Spillway Ditch at Hwy 102 near East Prairie, MO \\
Little River Ditch no. 251 near Lilbourn, MO \\
Main Ditch at Hwy 153 near White Oak, MO \\
Elk Chute near Gobler, MO \\
Cockle Burr Slough Ditch near Monette, AR \\
St. Francis River at Lake City, AR \\
Village Creek near Swifton, AR \\
Second Creek near Palestine, AR \\
\hline
\end{tabular}

\section{EXPLANATION}

Sites east of Crowleys Ridge

- Sites in Arkansas west of Crowleys Ridge

- Sites in Louisiana and Mississippi

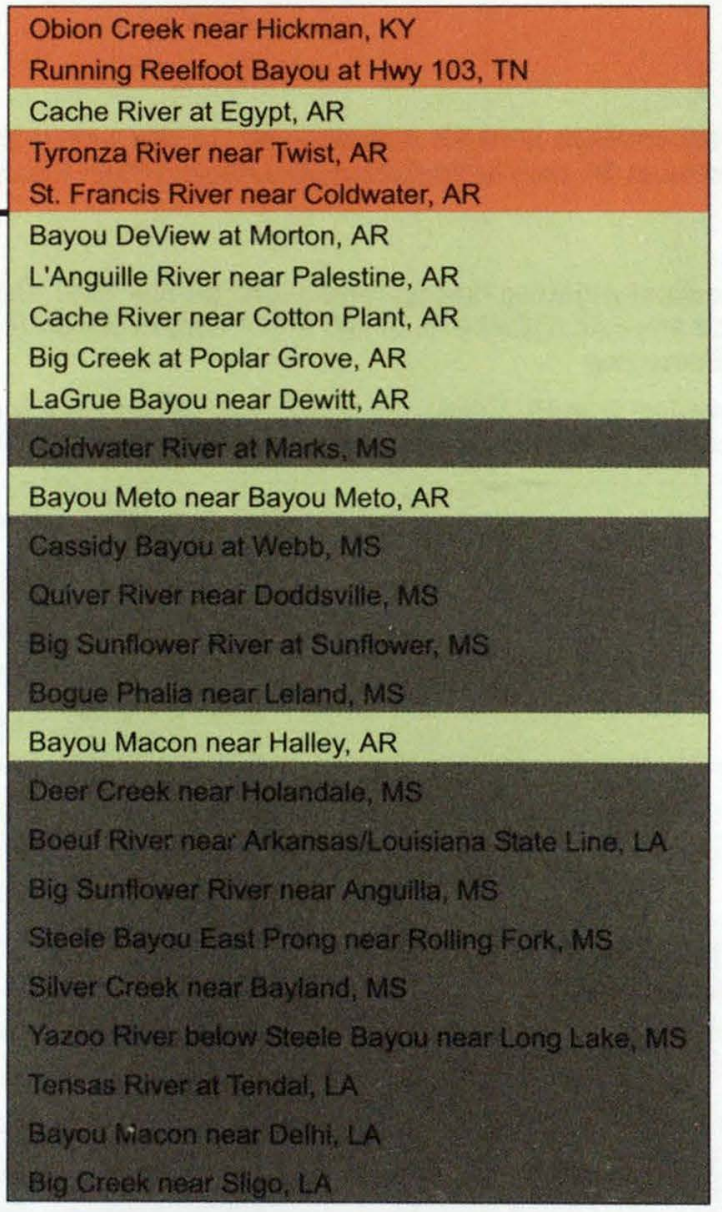

Figure 5. TWINSPAN dendogram showing first separation of fish community samples collected at 36 sites in the Mississippi Alluvial Plain Ecoregion in 1998.

16 An Index of Ecological Integrity for the Mississippi Alluvial Plain Ecoregion: Index Development and Relations to Selected Landscape Variabies 


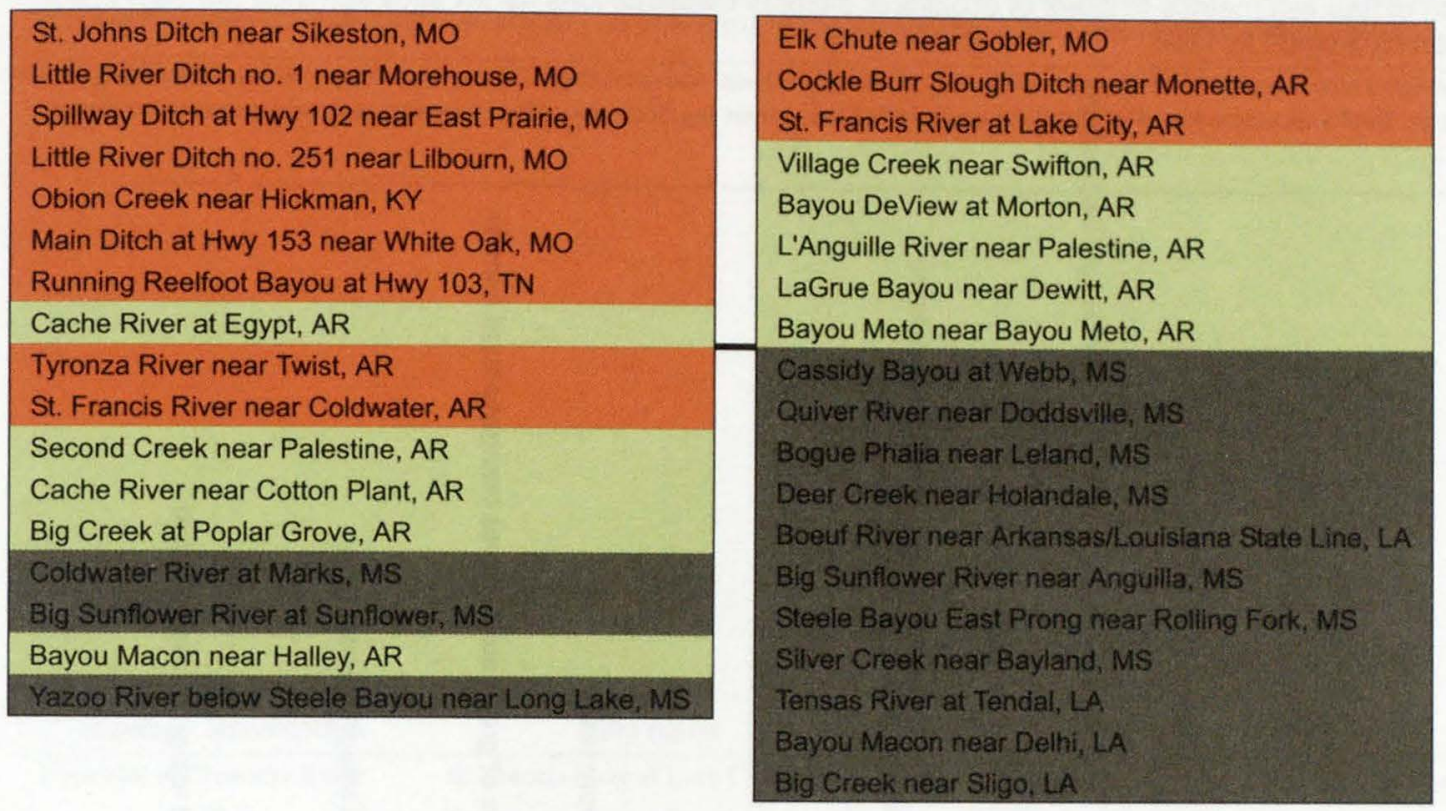

\section{EXPLANATION}

- Sites east of Crowleys Ridge

- Sites in Arkansas west of Crowleys Ridge

- Sites in Louisiana and Mississippi

Figure 6. TWINSPAN dendogram showing first separation of macroinvertebrate community samples collected at 36 sites in the Mississippi Plain Ecoregion in 1997.

Individual classifications by the four fish metrics of the two sites selected (the sites having the least degraded and most degraded water chemistry for all sites) from each a priori classification (table 7) varied in a manner similar to water quality at the six sites (table 8). In only one case (of 12) did a metric indicate the inverse of the water-quality data. This occurred for "the number of insectivore taxa," for the two sites in the Louisiana and Mississippi classification (table 7). Insectivore metrics have been used in other indices (Halliwell and others, 1999; Barbour and others, 1999), indicating that this metric is ecologically relevant in other regions, so the metric was not removed from the index.

Inter-reach (spatial) variability of the four biological metrics used in the index at two three-reach sites ranged from 0.17 to 0.43 ; inter-year (temporal) variability was slightly higher and ranged from 0.27 to 0.79 (table 9). Spatial variability and temporal variabil- ity for one of the metrics, the sum of lengths for all black bass, were high (spatial CV $=0.43$, temporal CV $=0.79$ ) relative to the other three biological metrics. The fact that some $\mathrm{CV}$ values were high may be related to the small number of multiple-reach and multipleyear samples collected during this study. Of 138 macroinvertebrate metrics evaluated nationally for NAWQA, the average CV for 34 metrics collected at less than 40 multiple-reach sites was 0.99 , whereas the average $\mathrm{CV}$ for 104 metrics collected at more than 40 multiple-reach sites was 0.34 (Tom Cuffney, U.S. Geological Survey, written commun., 2000).

Of the 41 chemical and physical metrics considered for the IEI, 15 metrics had correlations greater than 0.50 (Spearman's rho, $\mathrm{p}<0.001$ ) with DCAF1 site scores (table 6). Of those 15 metrics, two metrics-mean turbidity and mean total ammonia plus organic nitrogen-were used in the IEI. The remaining 13 chemical and physical metrics were not retained for the IEI for 
Table 7. A comparison of four fish metrics to index of ecological integrity classifications for six sites sampled (for fish) in the Mississippi Alluvial Plain Ecoregion in 1998

[Numbers in the table are centered metric scores at the two sites suspected of having the least- and most-degraded water chemistry within each of three $a$ priori classifications (see table 8 ). Bold indicates where sites that were suspected of being least degraded scored less than sites that were suspected of being most degraded]

\begin{tabular}{|c|c|c|c|c|c|c|c|}
\hline A priori classification & Site name & 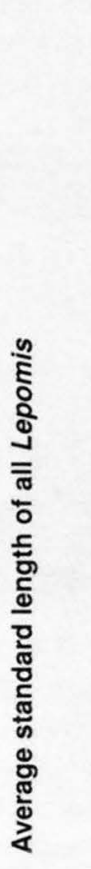 & 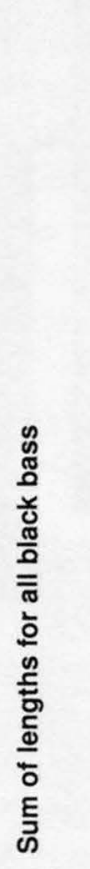 & 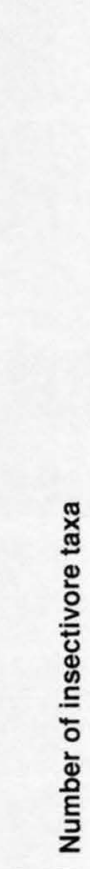 & 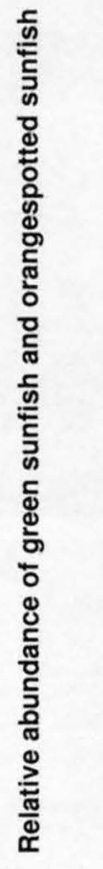 & 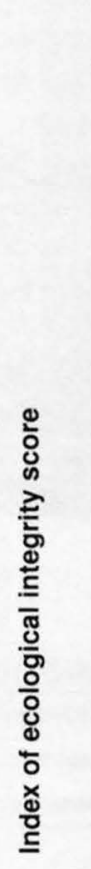 & 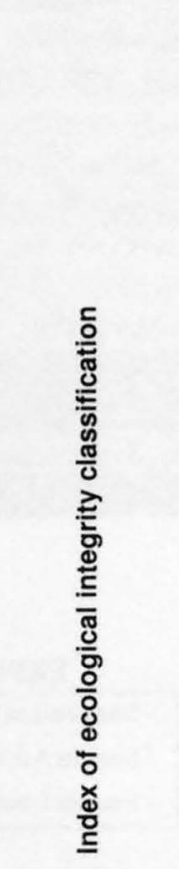 \\
\hline \multirow[t]{2}{*}{ Sites east of Crowleys Ridge } & St. Francis River at Lake City, AR & 8.17 & 10.00 & 10.00 & 9.29 & 89.83 & least degraded \\
\hline & Tyronza River near Twist, AR & 2.28 & 0.00 & 4.17 & 0.00 & 37.42 & most degraded \\
\hline Sites west and south of & LaGrue Bayou near Dewitt, AR & 10.00 & 1.97 & 4.17 & 9.43 & 68.47 & least degraded \\
\hline Crowleys Ridge & Cache River at Egypt, AR & 2.47 & 0.00 & 3.33 & 8.89 & 38.61 & most degraded \\
\hline Sites in Louisiana & Big Creek near Sligo, LA & 6.79 & 2.36 & 1.67 & 8.70 & 54.15 & least degraded \\
\hline and Mississippi & Cassidy Bayou at Webb, MS & 4.51 & 0.07 & 2.50 & 3.04 & 16.87 & most degraded \\
\hline
\end{tabular}


Table 8. Selected water-quality data for six sites in the Mississippi Alluvial Plain Ecoregion belonging to three a priori classifications

[Bold indicates where sites that seemed to have the most favorable water chemistry had values higher than or equal to values at sites that seemed to have the least favorable water chemistry; $\mu \mathrm{g} / \mathrm{L}$, micrograms per liter; $\mathrm{mg} / \mathrm{L}$, milligrams per liter, NTU, nephelometric turbidity units]

\begin{tabular}{|c|c|c|c|c|c|c|c|}
\hline A priori classification & Site name & 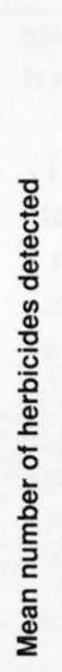 & 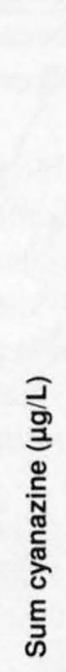 & 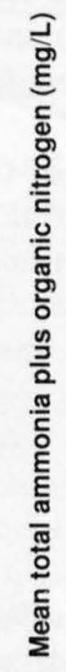 & 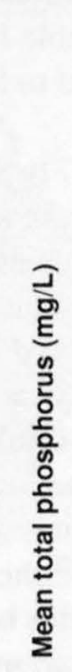 & 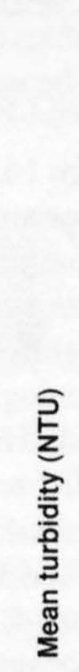 & 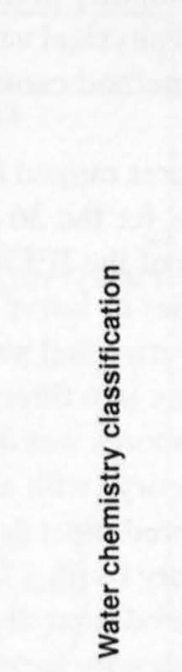 \\
\hline \multirow[t]{2}{*}{ Sites east of Crowleys Ridge } & St. Francis River at Lake City, AR & 4 & 0.00 & 0.48 & 0.14 & 17.7 & Least degraded \\
\hline & Tyronza River near Twist, AR & 9 & 0.46 & 0.47 & 0.19 & 24.1 & Most degraded \\
\hline \multirow{2}{*}{$\begin{array}{l}\text { Sites west and south of } \\
\text { Crowleys Ridge }\end{array}$} & LaGrue Bayou near Dewitt, AR & 3 & 0.00 & 0.59 & 0.10 & 23.3 & Least degraded \\
\hline & Cache River at Egypt, AR & 6 & 0.00 & 1.36 & 0.21 & 49.5 & Most degraded \\
\hline \multirow{2}{*}{$\begin{array}{l}\text { Sites in Louisiana } \\
\text { and Mississippi }\end{array}$} & Big Creek near Sligo, LA & 10 & 2.65 & 0.92 & 0.27 & 36.7 & Least degraded \\
\hline & Cassidy Bayou at Webb, MS & 14 & 5.92 & 2.13 & 0.58 & 134.7 & Most degraded \\
\hline
\end{tabular}

Table 9. Coefficient of variation (CV) for four fish metrics measured at two multiple-reach sites in 1996, and at six multipleyear sites from 1996 to 1998

\begin{tabular}{|c|c|c|c|c|c|c|}
\hline \multirow{2}{*}{ Metric } & \multicolumn{3}{|c|}{ CV for two sites } & \multicolumn{3}{|c|}{ CV for six sites } \\
\hline & Site 1 & Site 2 & Average & Minimum & Maximum & Average \\
\hline Sum of lengths for all black bass & 0 & 0.86 & 0.43 & 0 & 1.7 & 0.79 \\
\hline Number of insectivore taxa & 0 & 0.43 & 0.22 & 0.16 & 0.62 & 0.36 \\
\hline
\end{tabular}

the following reasons: five nutrient metrics were not used because of high correlations with mean total ammonia plus organic nitrogen; four metrics were not used because of high analytical costs; two metrics were not used

because they lacked ecological relevance (elevation was highly correlated but the range of elevation for the 36 sites is between 80 and 85 meters, and almost all species collected can be found throughout this range); one metric was not used because of high diurnal variability (water temperature was not measured at the same time on every day or at every site); and one metric was not used because it seemed unlikely that all field personnel could use the metric with the same level of consistency (table 6).

A comparison of the centering and ranking scoring methods indicated that the methods provided prac- 
tically the same results (Spearman's rho -0.98 , p < 0.001 ; fig. 7). The centering method was selected over the ranking method for the IEI because the centering method had slightly higher correlations to selected chemical and physical variables (table 10), and because the ranking method cannot be used to identify skewed data.

IEI scores ranged from 16.87 to 89.83 (table 11). Metric values for the 36 sites are provided to facilitate modification of the IEI if metric values at future test sites are higher or lower than values at these 36 sites. As a conservative and straightforward means of separating the sites into three ecological categories, the range of IEI scores was divided by four; sites scoring in the first category (with an IEI score lower than 35.11) were considered most degraded; sites scoring in the fourth category (with a IEI score higher than 71.59) were considered least degraded; sites between the first and fourth category were considered moderately degraded (table 11, fig. 8). All six of the streams in the least degraded category are located east of Crowleys Ridge. The seven streams in the most degraded category are located in Louisiana and Mississippi.
Table 10. Correlations of values calculated with two scoring methods considered for an index of ecological integrity in the Mississippi Alluvial Plain Ecoregion to selected chemical and physical metrics

[All correlations had $p$ values $<0.001$; bold denotes highest correlation of the two scoring methods]

\begin{tabular}{lccc}
\hline \multicolumn{1}{c}{ Metric } & $\begin{array}{c}\text { Metric } \\
\text { number }\end{array}$ & $\begin{array}{c}\text { Centering } \\
\text { method }\end{array}$ & $\begin{array}{c}\text { Ranking } \\
\text { method }\end{array}$ \\
\hline DDT (in fish tissue), total & 1 & 0.74 & -0.74 \\
Elevation & 2 & $\mathbf{- 0 . 7 7}$ & 0.74 \\
Fluometuron, sum & 3 & $\mathbf{0 . 6 5}$ & -0.64 \\
Latitude & 4 & -0.67 & $\mathbf{0 . 6 8}$ \\
$\begin{array}{l}\text { Macroinvertebrate habitat } \\
\quad \text { quality, estimated }\end{array}$ & 5 & $\mathbf{- 0 . 5 6}$ & 0.50 \\
$\begin{array}{l}\text { Number of herbicides } \\
\quad \text { detected, mean }\end{array}$ & 6 & $\mathbf{0 . 7 9}$ & -0.78 \\
Nitrate plus nitrite, dissolved & 7 & $\mathbf{0 . 7 1}$ & -0.67 \\
Nitrite, dissolved & 8 & $\mathbf{0 . 7 3}$ & -0.69 \\
Nitrogen, ammonia plus & 9 & $\mathbf{0 . 8 7}$ & $\mathbf{- 0 . 8 7}$ \\
$\quad$ organic dissolved & & & \\
Nitrogen, ammonia plus & 10 & 0.78 & $\mathbf{- 0 . 8 0}$ \\
$\quad$ organic total & & & \\
Nitrogen, ammonia dissolved & 11 & 0.58 & $\mathbf{- 0 . 6 3}$ \\
Phosphorus, total & 12 & $\mathbf{0 . 7 2}$ & -0.64 \\
Toxaphene (in fish tissue), total & 13 & 0.82 & $\mathbf{- 0 . 8 5}$ \\
Turbidity, mean & 14 & 0.78 & $-\mathbf{0 . 7 8}$ \\
Water temperature, mean & 15 & $\mathbf{0 . 7 4}$ & $-\mathbf{0 . 7 0}$ \\
\hline
\end{tabular}

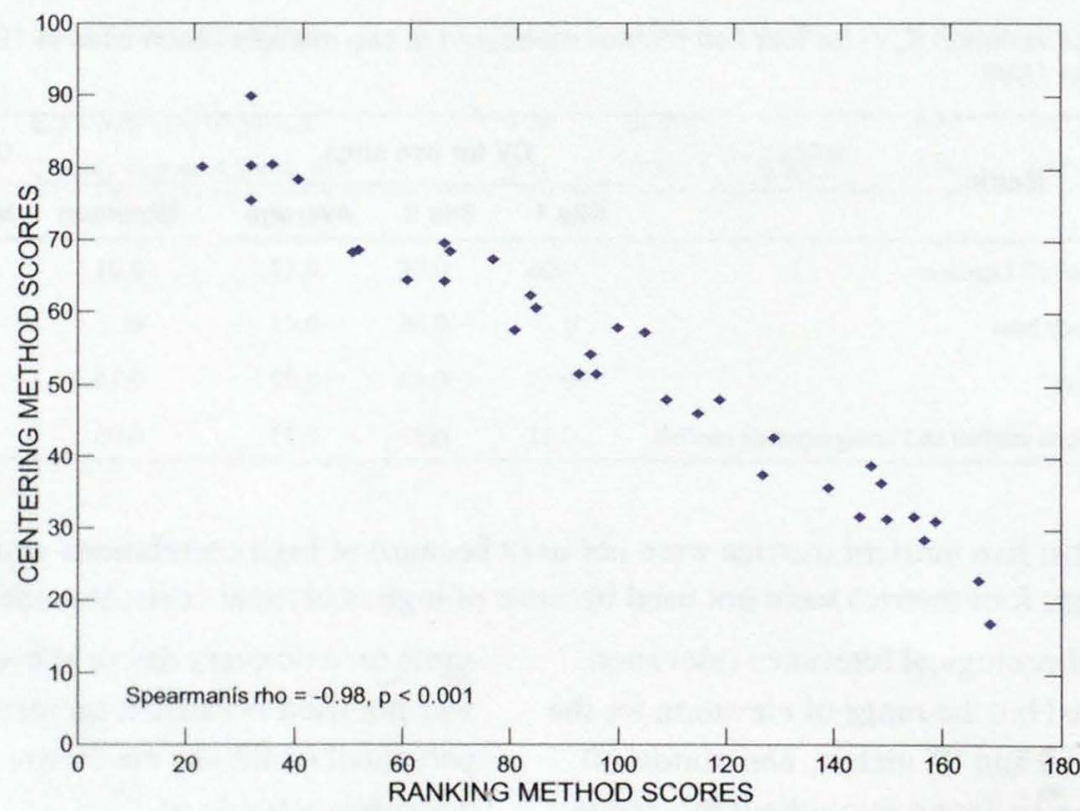

Figure 7. Comparison of two scoring methods evaluated for an index of ecological integrity in the Mississippi Alluvial Plain Ecoregion. 


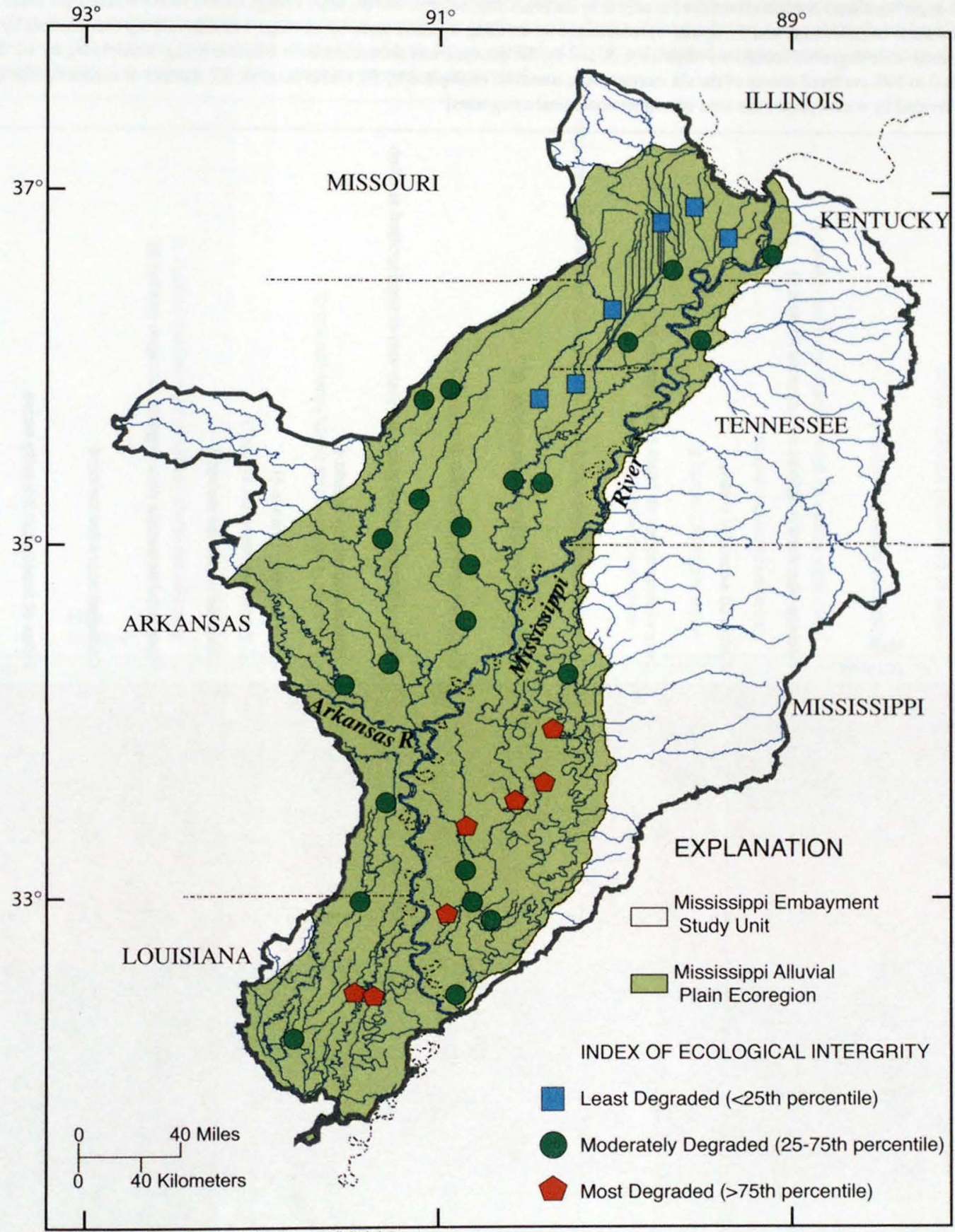

Base modified from U.S. Geological Survey digital data

$1: 2,000,000,1972$

Albers Equal-Area projection

Standard parallels $29^{\circ} 30^{\prime}$ and $45^{\circ} 30^{\prime}$; central meridian

Figure 8. Index of ecological integrity scores for 36 sites in the Mississippi Alluvial Plain Ecoregion. 
Table 11. Index of ecological integrity results (sorted by score) for 36 sites in the Mississippi Alluvial Plain Ecoregion

[The six "centered score" columns contain scores for the metric in the preceding column and the scores range from 1 to 10; where high metric scores indicate least-degraded conditions (metrics 1,2, and 3), scores were obtained by dividing a metric score by its range and multiplying the quotient by 10 ; where low metric scores indicated least-degraded conditions (metrics 4,5 , and 6 ), the quotient was subtracted from 1 before being multiplying by 10 . To produce an index ranging from 0 to 100 , centered scores of the six metrics were summed, multiplied by 10 , and divided by the number of metrics in the index. The range of IEI scores was divided by 4 to separate the sites into three ecological categories]

\begin{tabular}{|c|c|c|c|c|c|c|c|c|c|c|c|c|c|c|c|}
\hline Site name & $\begin{array}{l}\text { Map } \\
\text { number }\end{array}$ & 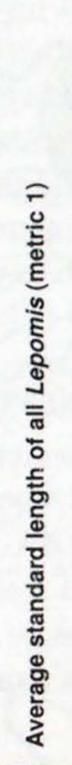 & 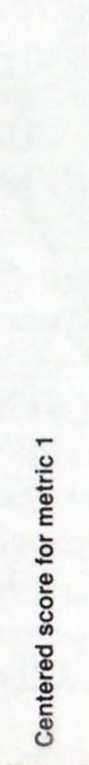 & 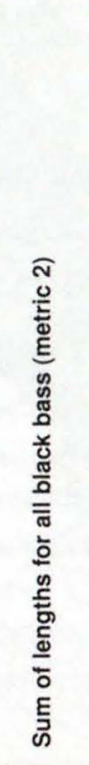 & 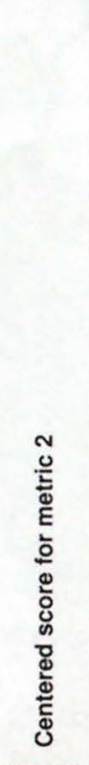 & 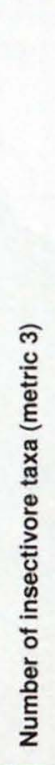 & 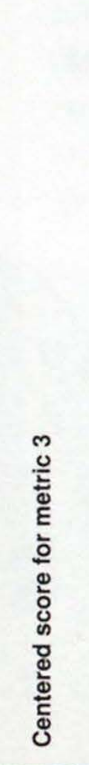 & 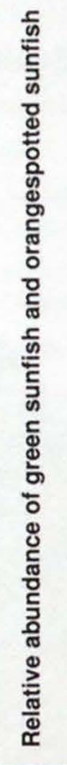 & 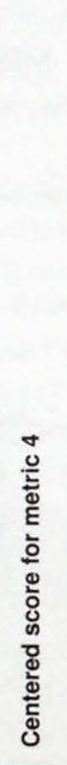 & 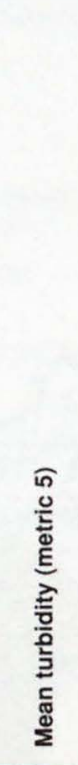 & 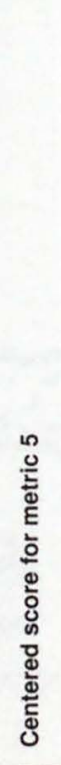 & 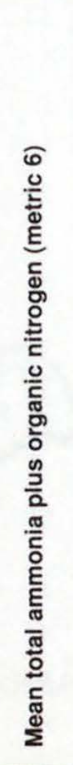 & 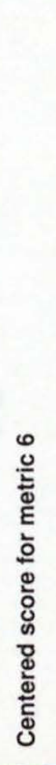 & 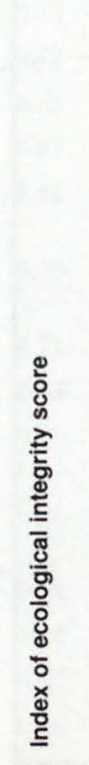 & 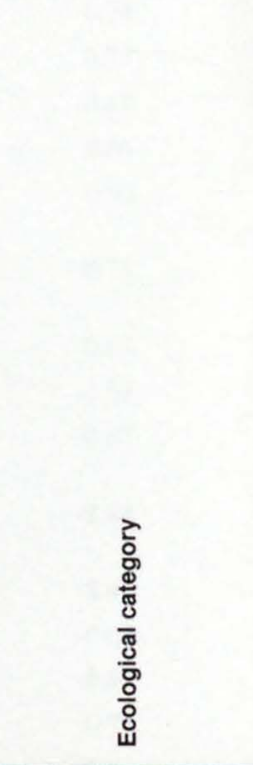 \\
\hline $\begin{array}{l}\text { St. Francis River } \\
\text { at Lake City, AR }\end{array}$ & 10 & 77.4 & 8.17 & 6,522 & 10.00 & 12 & 10.00 & 0.1 & 9.3 & 17.7 & 8.7 & 0.48 & 7.8 & 89.83 & Least degraded \\
\hline $\begin{array}{l}\text { Main Ditch at } \\
\text { Hwy } 153 \text { near } \\
\text { White Oak, MO }\end{array}$ & 5 & 66.2 & 6.98 & 3,433 & 5.26 & 10 & 8.33 & 0.2 & 8.4 & 3.4 & 9.7 & 0.10 & 9.5 & 80.44 & Least degraded \\
\hline $\begin{array}{l}\text { Cockle Burr } \\
\text { Slough Ditch near } \\
\text { Monette, AR }\end{array}$ & 2 & 68.1 & 7.19 & 3,028 & 4.64 & 11 & 9.17 & 0 & 9.6 & 17.3 & 8.7 & 0.26 & 8.8 & 80.22 & Least degraded \\
\hline $\begin{array}{l}\text { St. Johns Ditch } \\
\text { near Sikeston, MO }\end{array}$ & 6 & 89.5 & 9.44 & 2,571 & 3.94 & 8 & 6.67 & 0 & 9.9 & 6.1 & 9.6 & 0.30 & 8.6 & 80.08 & Least degraded \\
\hline $\begin{array}{l}\text { Little River Ditch } \\
\text { no. } 1 \text { near More- } \\
\text { house, MO }\end{array}$ & 9 & 70.1 & 7.40 & 3,599 & 5.52 & 10 & 8.33 & 0.2 & 7.9 & 16.6 & 8.8 & 0.19 & 9.1 & 78.37 & Least degraded \\
\hline $\begin{array}{l}\text { Spillway Ditch at } \\
\text { Hwy } 102 \text { near } \\
\text { East Prairie, MO }\end{array}$ & 3 & 76.8 & 8.10 & 2,843 & 4.36 & 7 & 5.83 & 0 & 9.6 & 9.9 & 9.3 & 0.40 & 8.1 & 75.48 & Least degraded \\
\hline $\begin{array}{l}\text { Obion Creek near } \\
\text { Hickman, KY }\end{array}$ & 1 & 60.9 & 6.42 & 4,217 & 6.47 & 7 & 5.83 & 0 & 10 & 38.0 & 7.2 & 0.89 & 5.8 & 69.52 & Moderately degraded \\
\hline $\begin{array}{l}\text { LaGrue Bayou } \\
\text { near Dewitt, AR }\end{array}$ & 17 & 94.8 & 10.00 & 1,286 & 1.97 & 5 & 4.17 & 0.1 & 9.4 & 23.3 & 8.3 & 0.59 & 7.2 & 68.47 & Moderately degraded \\
\hline $\begin{array}{l}\text { Bayou DeView at } \\
\text { Morton, AR }\end{array}$ & 12 & 81.1 & 8.56 & 1,673 & 2.57 & 9 & 7.50 & 0.1 & 9 & 38.5 & 7.1 & 0.80 & 6.2 & 68.36 & Moderately degraded \\
\hline $\begin{array}{l}\text { Village Creek near } \\
\text { Swifton, AR }\end{array}$ & 4 & 92.6 & 9.77 & 2,131 & 3.27 & 4 & 3.33 & 0.1 & 9.4 & 9.8 & 9.3 & 0.87 & 5.9 & 68.27 & Moderately degraded \\
\hline $\begin{array}{l}\text { Little River Ditch } \\
\text { no. } 251 \text { near Lil- } \\
\text { bourn, MO }\end{array}$ & 16 & 62.1 & 6.55 & 2,095 & 3.21 & 11 & 9.17 & 0.4 & 6.3 & 31.8 & 7.6 & 0.55 & 7.4 & 67.21 & Moderately degraded \\
\hline $\begin{array}{l}\text { Second Creek near } \\
\text { Palestine, AR }\end{array}$ & 8 & 76.5 & 8.07 & 1,719 & 2.64 & 5 & 4.17 & 0.1 & 8.6 & 21.5 & 8.4 & 0.69 & 6.7 & 64.36 & Moderately degraded \\
\hline $\begin{array}{l}\text { Big Creek at Pop- } \\
\text { lar Grove, AR }\end{array}$ & 15 & 69.2 & 7.30 & 959 & 1.47 & 7 & 5.83 & 0 & 9.5 & 28.5 & 7.9 & 0.75 & 6.5 & 64.13 & Moderately degraded \\
\hline
\end{tabular}

22 An Index of Ecological Integrity for the Mississippi Alluvial Plain Ecoregion: Index Development and Relations to Selected Landscape Variables 
Table 11. Index of ecological integrity results (sorted by score) for 36 sites in the Mississippi Alluvial Plain Ecoregion --Continued

[The six "centered score" columns contain scores for the metric in the preceding column and the scores range from 1 to 10; where high metric scores indicate least-degraded conditions (metrics 1,2, and 3 ), scores were obtained by dividing a metric score by its range and multiplying the quotient by 10 ; where low metric scores indicated least-degraded conditions (metrics 4,5 , and 6 ), the quotient was subtracted from 1 before being multiplying by 10 . To produce an index ranging from 0 to 100 , centered scores of the six metrics were summed, multiplied by 10 , and divided by the number of metrics in the index. The range of IEI scores was divided by 4 to separate the sites into three ecological categories]

\begin{tabular}{|c|c|c|c|c|c|c|c|c|c|c|c|c|c|c|c|}
\hline Site name & $\begin{array}{l}\text { Map } \\
\text { number }\end{array}$ & 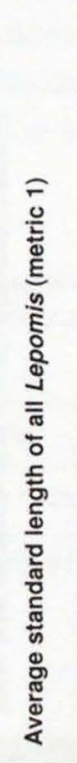 & 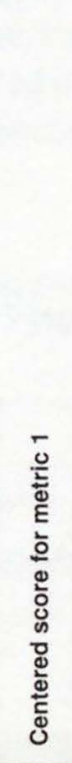 & 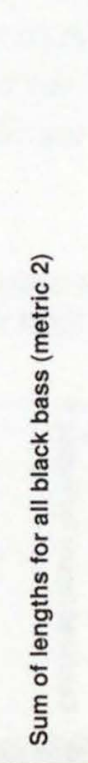 & 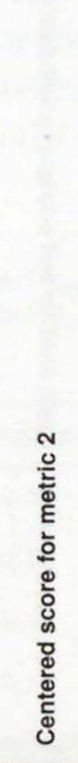 & 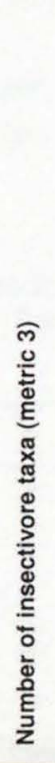 & 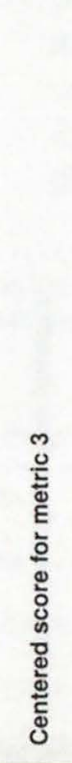 & 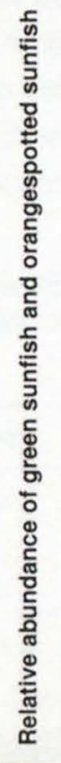 & 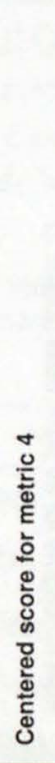 & 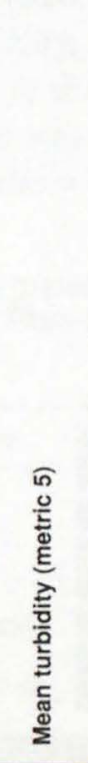 & 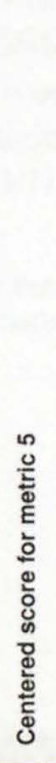 & 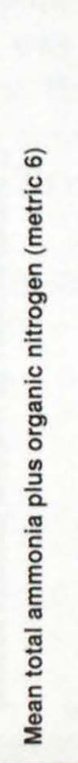 & 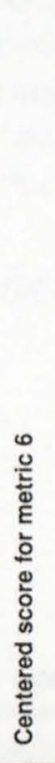 & 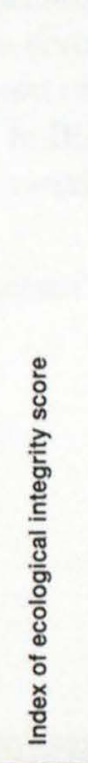 & 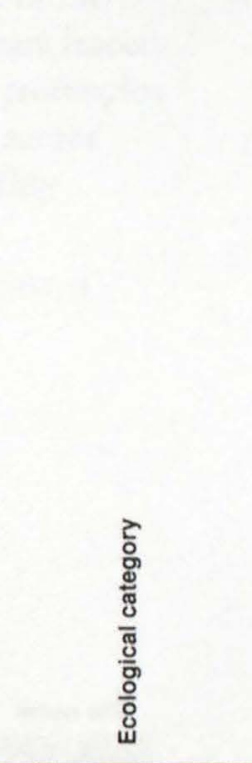 \\
\hline $\begin{array}{l}\text { Cache River near } \\
\text { Cotton Plant, AR }\end{array}$ & 32 & 76.3 & 8.05 & 605 & 0.93 & 9 & 7.50 & 0.2 & 8.3 & 49.5 & 6.3 & 0.79 & 6.3 & 62.34 & Moderately degraded \\
\hline $\begin{array}{l}\text { L'Anguille River } \\
\text { near Palestine, AR }\end{array}$ & 36 & 55.5 & 5.85 & 2,157 & 3.31 & 6 & 5.00 & 0.2 & 8.1 & 26.3 & 8.1 & 0.84 & 6.1 & 60.55 & Moderately degraded \\
\hline $\begin{array}{l}\text { Bayou Meto near } \\
\text { Bayou Meto, AR }\end{array}$ & 20 & 58.8 & 6.20 & 404 & 0.62 & 8 & 6.67 & 0.3 & 7.1 & 23.7 & 8.2 & 0.88 & 5.9 & 57.82 & Moderately degraded \\
\hline $\begin{array}{l}\text { St. Francis River } \\
\text { near Coldwater, } \\
\text { AR }\end{array}$ & 19 & 84.0 & 8.86 & 236 & 0.36 & 5 & 4.17 & 0 & 10 & 68.3 & 4.9 & 0.82 & 6.2 & 57.45 & Moderately degraded \\
\hline $\begin{array}{l}\text { Elk Chute near } \\
\text { Gobler, MO }\end{array}$ & 33 & 50.7 & 5.35 & 1,715 & 2.63 & 9 & 7.50 & 0.4 & 5.6 & 35.5 & 7.4 & 0.90 & 5.8 & 57.15 & Moderately degraded \\
\hline $\begin{array}{l}\text { Big Creek near } \\
\text { Sligo, LA }\end{array}$ & 18 & 64.3 & 6.79 & 1.541 & 2.36 & 2 & 1.67 & 0.1 & 8.7 & 36.7 & 7.3 & 0.92 & 5.7 & 54.15 & Moderately degraded \\
\hline $\begin{array}{l}\text { Silver Creek near } \\
\text { Bayland, MS }\end{array}$ & 31 & & 6.37 & 1,607 & 2.46 & 3 & 2.50 & 0.1 & 9 & 15.8 & 8.8 & 1.77 & 17 & 51.41 & Moderarely degraded \\
\hline $\begin{array}{l}\text { Yazoo River } \\
\text { below Steele } \\
\text { Bayon near Long } \\
\text { Lake, MS }\end{array}$ & 28 & 52.5 & 5.54 & 732 & 1.12 & 8 & 6.67 & 0 & 9.5 & 120.5 & 1.1 & 0.66 & 6.9 & 51.38 & Moderately degraded \\
\hline $\begin{array}{l}\text { Bayou Macon } \\
\text { near Halley, AR }\end{array}$ & 35 & 50.2 & 5.30 & 43 & 0.07 & 3 & 2.50 & 0.3 & 6.8 & 30.7 & 7.7 & 0.78 & 6.3 & 47.83 & Moderately degraded \\
\hline $\begin{array}{l}\text { Running Reelfoot } \\
\text { Bayou at Hwy } \\
103, \mathrm{TN}\end{array}$ & 22 & 32.2 & 3.40 & 102 & 0.16 & 3 & 2.50 & 0.3 & 7.3 & 18.3 & 8.6 & 0.72 & 6.6 & 47.78 & Moderately degraded \\
\hline $\begin{array}{l}\text { Deer Creek near } \\
\text { Hellandale, MS }\end{array}$ & 14 & 61.0 & 6.43 & 445 & 0.68 & 3 & 2.50 & 0.3 & 7.4 & 50.7 & 6.2 & 1.20 & 4,3 & 45.98 & Moderately degraded \\
\hline $\begin{array}{l}\text { Boeuf River near } \\
\text { Arkansas } 1 \text { a State } \\
\text { Line, LA }\end{array}$ & 30 & 63.6 & 6.71 & 51 & 0.08 & 2 & 1.67 & 0.3 & 7. & 53.5 & 6.0 & 1.28 & 40 & 42.52 & Moderately degraded \\
\hline $\begin{array}{l}\text { Cache River at } \\
\text { Egypt, AR }\end{array}$ & 25 & 23.4 & 2.47 & 0 & 0.00 & 4 & 3.33 & 0.1 & 8.9 & 69.2 & 4.9 & 1.36 & 3.6 & 38.61 & Moderately degraded \\
\hline
\end{tabular}


Table 11. Index of ecological integrity results (sorted by score) for 36 sites in the Mississippi Alluvial Plain Ecoregion --Continued

[The six "centered score" columns contain scores for the metric in the preceding column and the scores range from 1 to 10 ; where high metric scores indicate least-degraded conditions (metrics 1,2, and 3), scores were obtained by dividing a metric score by its range and multiplying the quotient by 10 ; where low metric scores indicated least-degraded conditions (metrics 4,5 , and 6 ), the quotient was subtracted from 1 before being multiplying by 10 . To produce an index ranging from 0 to 100 , centered scores of the six metrics were summed, multiplied by 10 , and divided by the number of metrics in the index. The range of IEI scores was divided by 4 to separate the sites into three ecological categories]

\begin{tabular}{|c|c|c|c|c|c|c|c|c|c|c|c|c|c|c|c|}
\hline Site name & $\begin{array}{l}\text { Map } \\
\text { number }\end{array}$ & 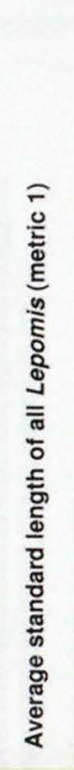 & 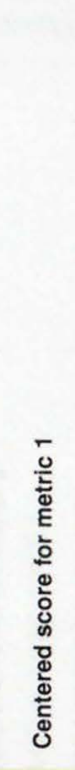 & 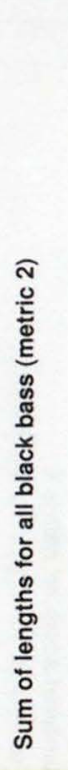 & 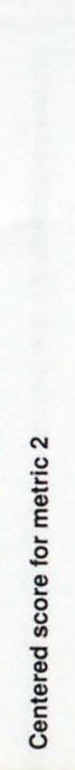 & 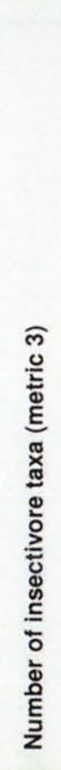 & 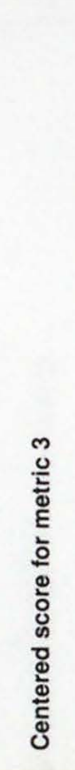 & 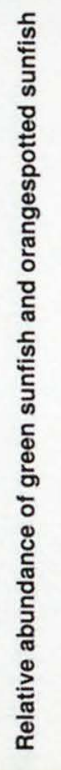 & 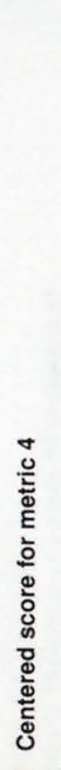 & 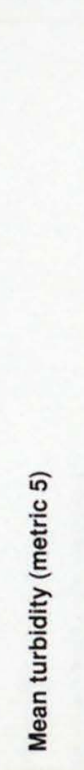 & 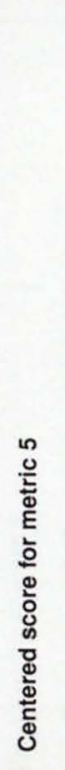 & 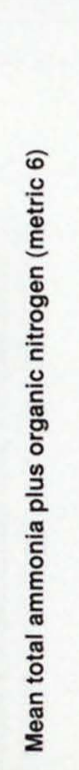 & 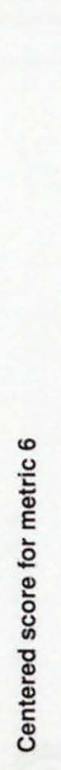 & 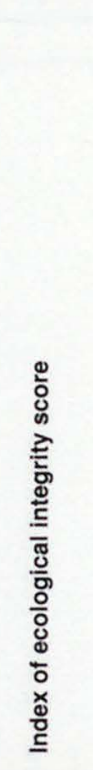 & 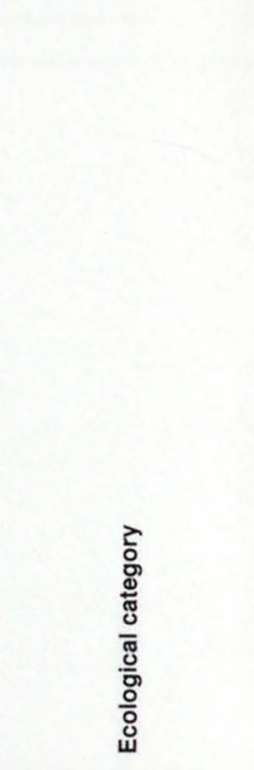 \\
\hline $\begin{array}{l}\text { Cache River at } \\
\text { Egypt, AR }\end{array}$ & 25 & 23.4 & 2.47 & 0 & 0.00 & 4 & 3.33 & 0.1 & 8.9 & 69.2 & 4.9 & 1.36 & 3.6 & 38.61 & Moderately degraded \\
\hline $\begin{array}{l}\text { Tyronza River } \\
\text { near Twist, AR }\end{array}$ & 7 & 21.6 & 2.28 & 0 & 0.00 & 5 & 4.17 & 1 & 0 & 24.1 & 8.2 & 0.47 & 7.8 & 37.42 & Moderately degraded \\
\hline $\begin{array}{l}\text { Coldwater. River } \\
\text { at Marks, MS }\end{array}$ & 26 & 34.4 & 3.63 & 37 & 0.06 & 6 & $5.00^{\circ}$ & 0.7 & 3.3 & 82.7 & 3.9 & 0.87 & 5.9 & 36.32 & Moderately degraded \\
\hline $\begin{array}{l}\text { Big Sunflower } \\
\text { River near } \\
\text { Anguilla, MS }\end{array}$ & 29 & 56.7 & 5.98 & 234 & 0,36 & 1 & 0.83 & 0.5 & 5.2 & 75,0 & 4.4 & 1.16 & 4.6 & 35.64 & Moderately degraded \\
\hline $\begin{array}{l}\text { Bogue Phalia near } \\
\text { Leland, MS }\end{array}$ & 23 & 35.2 & 3.71 & 66 & 0.10 & 5 & 4.17 & 0.6 & 4 & 78.7 & 4.2 & 1.53 & 2.8 & 31.61 & Most degraded \\
\hline $\begin{array}{l}\text { Stecle Bayou East } \\
\text { Prong near Roll- } \\
\text { ing Fork, MS }\end{array}$ & 27 & 37.2 & 3.92 & 498 & 0.76 & 2 & 1.67 & 0.6 & 3.7 & 58.7 & 5.6 & 1.43 & 3.3 & 31.61 & Most degraded \\
\hline $\begin{array}{l}\text { Bayou Macon } \\
\text { near Dethi, LA }\end{array}$ & 21 & 47.5 & 5.01 & 406 & 0.62 & 1 & 0.83 & 0.3 & 6.7 & 94.5 & 3.0 & 1.58 & 2.6 & 31.26 & Most degraded \\
\hline $\begin{array}{l}\text { Tensas River at } \\
\text { Tendal, L.A }\end{array}$ & 24 & 26.5 & 2.79 & 0 & 0.00 & 3 & 2,50 & 0.7 & 3.3 & 52.5 & 6.1 & 1.30 & 3.9 & 31.05 & Most degraded \\
\hline $\begin{array}{l}\text { Big Sunflower } \\
\text { River at Sun- } \\
\text { flower, MS }\end{array}$ & 11 & 219 & 2.31 & 156 & 0.24 & 5 & 4.17 & 0.7 & 3.3 & 95.2 & 2.9 & 1.27 & 4.1 & 28.41 & Most degraded \\
\hline $\begin{array}{l}\text { Quiver River near } \\
\text { Doddsville, MS }\end{array}$ & 13 & 20.3 & 2.14 & 27 & 0.04 & 4 & 3.33 & 1 & 0 & 74.7 & 4.5 & 1.34 & 3.7 & 22.78 & Most degraded \\
\hline $\begin{array}{l}\text { Cassidy Bayou at } \\
\text { Webb, MS }\end{array}$ & 34 & 42.7 & 4.51 & 47 & 0.07 & .3 & 2.50 & 0.7 & 3.0 & 134.7 & 2,4 & 2.15 & 0 & 16.87 & Most degracied \\
\hline
\end{tabular}

24 An Index of Ecological Integrity for the Mississippi Alluvial Plain Ecoregion: Index Development and Relations to Selected Landscape Variables 


\section{RESULTS FOR RELATING THE IEI TO LANDSCAPE VARIABLES}

Of the 148 landscape variables evaluated, the percentage of Holocene deposits and cotton pesticide use rates had the highest correlations to IEI results (table 12). Sites that had the highest IEI scores had the lowest percentages of Holocene deposits (compact alluvial clays that were deposited after the last glacier, fig. 9) and the lowest cotton insecticide use rates (figs. 10 and 11).
Of the 21 pesticide use rates having the highest correlations to IEI scores (absolute value for Spearman's rho $>0.60, \mathrm{p}<0.001), 13$ were cotton insecticides and 7 were cotton herbicides (table 12).

Profenofos, a cotton insecticide that has been linked to several fish kills in Louisiana and Mississippi (McPherson, 1996; Mississippi Department of Environmental Quality, 1996), was used to compare insecticide use rates to IEI scores. The amount of profenofos used per basin was highly correlated to IEI scores (Spearman's rho $=-0.71)$. To reduce variability

Table 12. Correlations for geologic properties and pesticide use rates that were greater than $|0.60|$ (Spearman's rho, $p>$ 0.001 ) with an index of ecological integrity established in the Mississippi Alluvial Plain Ecoregion

[NA, not applicable]

\begin{tabular}{|c|c|c|c|}
\hline Property or use rate ${ }^{1}$ & Correlation & Crop use & Type \\
\hline Percentage of Holocene deposits in the basin & -0.78 & NA & NA \\
\hline Percentage of Pleistocene deposits in the basin & 0.71 & NA & NA \\
\hline Endosulfan & -0.76 & Cotton & Insecticide \\
\hline Sulprofos & -0.75 & Cotton & Insecticide \\
\hline Methyl parathion & -0.72 & Cotton & Insecticide \\
\hline Acephate & -0.72 & Cotton & Insecticide \\
\hline Thiodicarb & -0.72 & Cotton & Insecticide \\
\hline Amitraz & -0.71 & Cotton & Insecticide \\
\hline Profenofos & -0.71 & Cotton & Insecticide \\
\hline Diuron & -0.70 & Cotton & Herbicide \\
\hline Lambdacyhalothin & -0.69 & Cotton & Insecticide \\
\hline Clomazone & -0.69 & Cotton & Herbicide \\
\hline Malathion & -0.68 & Cotton & Insecticide \\
\hline Azinphos methyl & -0.67 & Cotton & Insecticide \\
\hline Prometryn & -0.66 & Cotton & Herbicide \\
\hline Cyfluthrin & -0.66 & Cotton & Insecticide \\
\hline Fluazifop & -0.66 & $\begin{array}{l}\text { Cotton/Soy- } \\
\text { beans }\end{array}$ & Herbicide \\
\hline Lactofen & -0.66 & Cotton & Herbicide \\
\hline Cypermethrin & -0.65 & Cotton & Insecticide \\
\hline Esfenvalerate & -0.62 & Cotton & Insecticide \\
\hline Linuron & -0.62 & Cotton & Herbicide \\
\hline Mepiquat chloride & -0.60 & Cotton & Herbicide \\
\hline
\end{tabular}

${ }^{1}$ Use rates for 91 pesticides (insecticides, herbicides, fungicides, and defoliants) that were used on three major crops grown in the Mississippi Alluvial Plain Ecoregion were evaluated. 


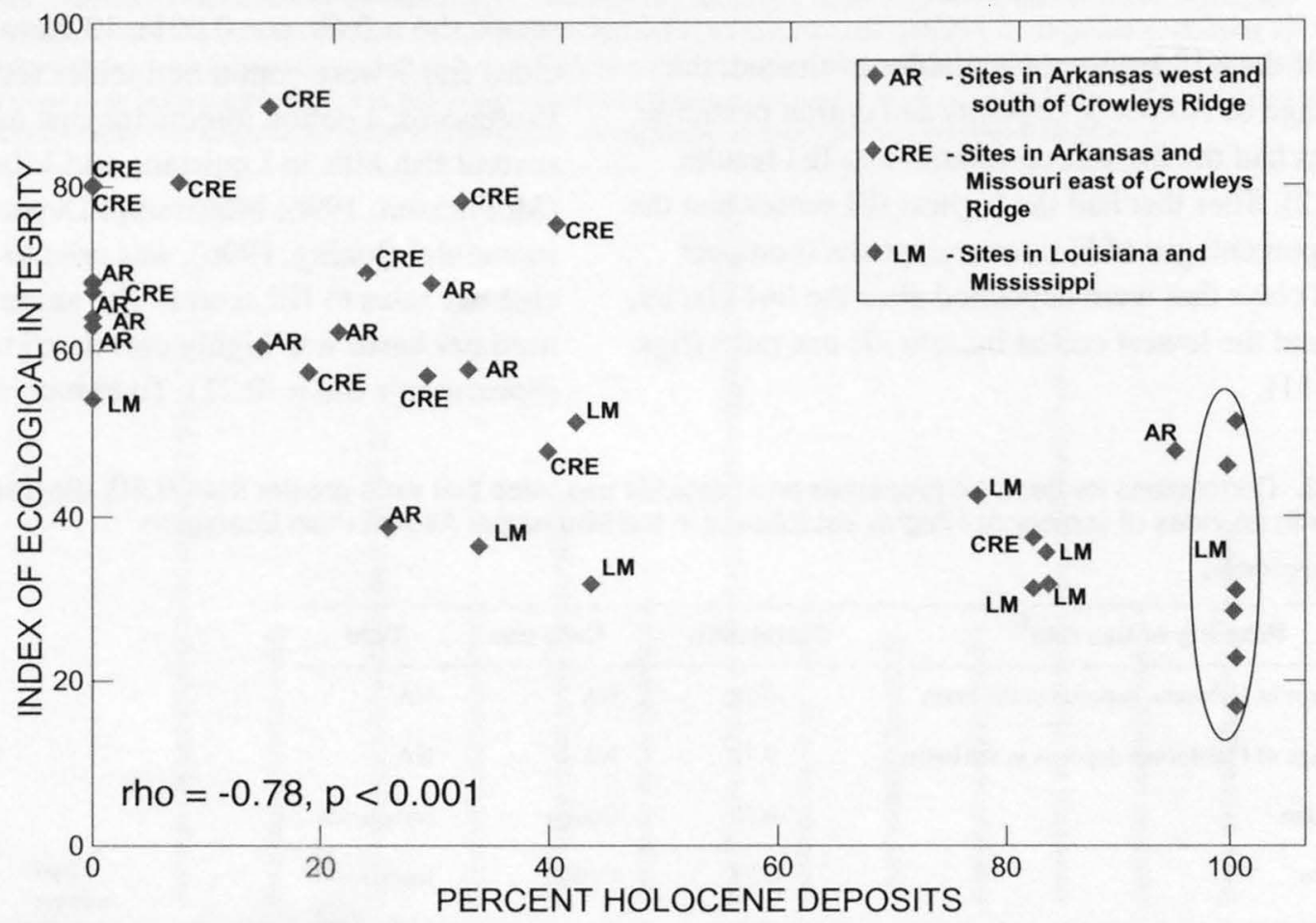

Figure 9. Scatter plot comparing index of ecological integrity scores to the percentage of Holocene deposits in the basins at 36 site samples in the Mississippi Alluvial Plain Ecoregion.

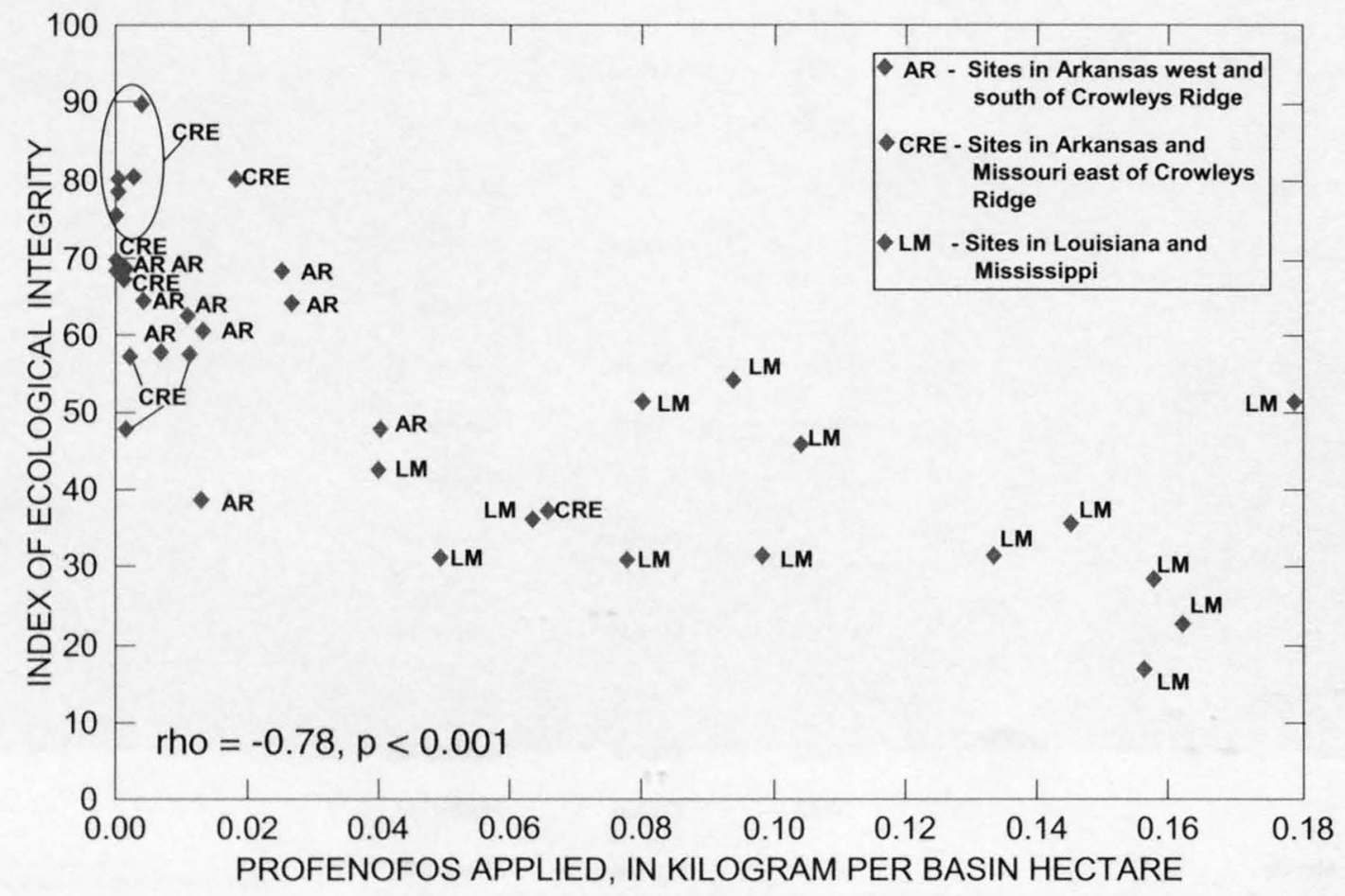

Figure 10. Scatter plot comparing index of ecological integrity scores to the amount of profenofos applied in 36 stream basins in the Mississippi Alluvial Plain Ecoregion. 


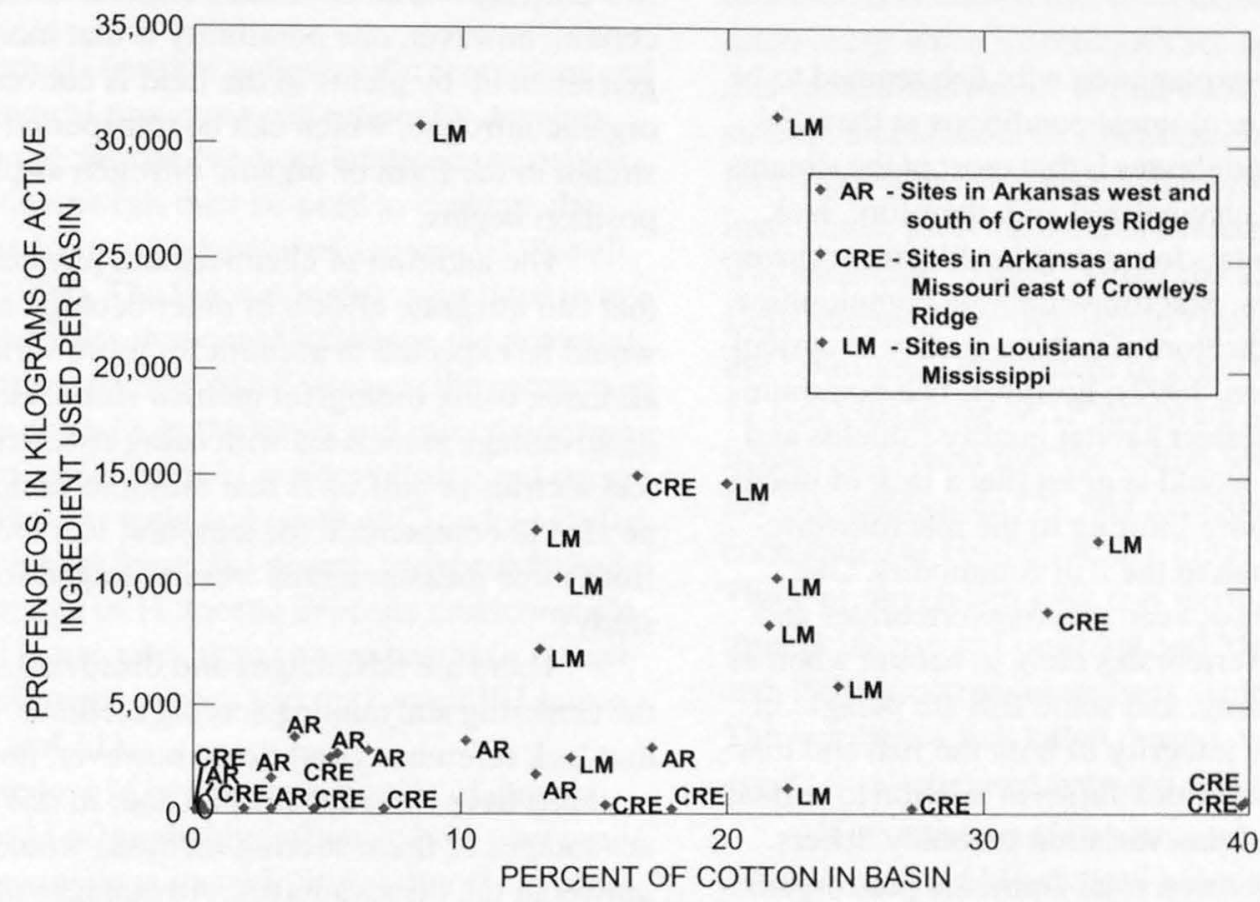

Figure 11. Scatter plot comparing the percentage of the basin in which cotton is grown and the amount of profenofos applied in 34 stream basins in the Mississippi Alluvial Plain Ecoregion.

associated with basin size (more insecticide generally would be applied in larger basins), the amount of profenofos used per hectare was calculated for all basins and then was compared to IEI scores (Spearman's rho = -0.78 ; fig. 10). The amount of profenofos used in each basin was also compared to the percent of cotton in each basin (fig. 11). Both comparisons indicate that profenofos use rates were higher for basins in Louisiana and Mississippi that had the lowest IEI scores, compared to basins in the two remaining a priori classifications that had higher IEI scores.

Because the relation between the chemical and physical variables in the index and the percentage of Holocene deposits and cotton pesticide use rates was uncertain, sums of the centered scores of the four biological metrics were correlated to the percentage of Holocene deposits in the basin, to the amount of profenofos applied per hectare in the basin, and to the amount of profenofos applied per hectare of cotton in the basin. Results indicate that the biological metrics alone had strong relations to the landscape variables (table 13).
Table 13. Correlations for the percentage of Holocene deposits and profenofos use rates in 36 basins to the sum of four biological metrics used in an index of ecological integrity in the Mississippi Alluvial Plain Ecoregion

[All correlations had $\mathrm{p}$ values $<0.001$ ]

\begin{tabular}{ll}
\hline \multicolumn{1}{c}{ Land use variable } & $\begin{array}{c}\text { Sum of centered scores } \\
\text { of biological metrics }\end{array}$ \\
\hline $\begin{array}{l}\text { Percentage of Holocene deposits } \\
\text { in the basin }\end{array}$ & -0.75 \\
Profenofos use rates per basin & -0.75 \\
$\begin{array}{l}\text { Profenofos use rates per hectare } \\
\text { of cotton }\end{array}$ & -0.75 \\
\hline
\end{tabular}




\section{DISCUSSION OF INDEX DEVELOPMENT PROCESSES}

One possible explanation why fish seemed to be better indicators of ecological conditions at these 36 sites than macroinvertebrates is that most of the streams sampled have been channelized and, therefore, lack sufficient microhabitats to support healthy macroinvertebrate communities. Macroinvertebrate communities seem to be good indicators of habitat quality in agricultural basins (Petersen, 1992); however, fish communities do not always reflect habitat quality (Shields and others, 1995). This would suggest that a lack of microhabitats might be more limiting to the macroinvertebrate community than to the fish community. One apparent difference between macroinvertebrates and fish is that macroinvertebrates cling to habitat whereas fish are free swimming, and some fish are pelagic in nature. Whereas the integrity of both the fish and macroinvertebrate communities varies in relation to habitat quality, the extent of this variation probably differs.

Turbidity and mean total ammonia plus organic nitrogen were used as metrics in this IEI for several reasons, the most important of which was that both metrics were ecologically relevant. Turbidity integrates different aspects of instream and riparian habitat characteristics such as the quality of vegetation along the stream banks and in the basin, bank and substrate stability, and soil characteristics in the basin.

Although it could be unique to the MAP, mean total ammonia plus organic nitrogen also seems to integrate different aspects of instream and riparian habitat characteristics. One could anticipate that all nitrogen constituents would be highest in areas with the highest fertilizer application rates. However, concentrations of total ammonia plus organic nitrogen, as well as other nitrogen constituents, were consistently higher in the southern part of the MAP (in Louisiana and Mississippi, where application rates are the lowest) than in the northern part of the MAP (in Arkansas and Missouri, where nitrogen use rates are highest; Battaglin and Goolsby, 1995). Total ammonia plus organic nitrogen is a measure of both ammonia and the total particulate and dissolved organic nitrogen, but organic nitrogen comprised most of the measurement at all 36 sites. Decomposing particulate and dissolved detritus are major sources for organic nitrogen (Wetzel and Likens, 1991). Data from this study, as well as agricultural field runoff data collected by the USGS in southern Arkansas (Barks and others, 2002) indicate that total organic nitrogen could be a surrogate for agricultural runoff potential in the MAP. The exact connection between row crop agriculture and total organic nitrogen is not certain; however, one possibility is that inorganic nitrogen taken up by plants in the field is converted to organic nitrogen, which can be transported to the stream in the form of organic nitrogen as plant decomposition begins.

The addition of chemical and physical metrics that can integrate effects of other ecological factors would be expected to account for more variability than an index using biological metrics alone. However, a disadvantage associated with using chemical and physical metrics in indices is that multiple samples are needed to compensate for temporal variability (results from three measurements were averaged for this study).

There are advantages and disadvantages to both the centering and ranking scoring methods. For regions that lack reference conditions, however, no scoring methods have been established and, in this case, the advantages of these scoring methods would obviously outweigh the disadvantages. Advantages of the two scoring methods include (a) low cost because the need to collect data from a large number of candidate reference sites is eliminated, (b) no scoring criteria need be established to classify metric performance, (c) the centering and ranking methods are more sensitive than the trisection method (observed first by Ganasan and Hughes, 1998) because the range of the centering method (1-36) and the ranking method (1-10) exceeds the range of the trisection method (1-5, Barbour and others, 1999), and (d) sequence gaps (the trisection method assigns a score of 1,3 , or 5 , leaving 2 and 4 as sequence gaps) are not problematic because both methods use a continuous scoring system. Disadvantages of the centering and ranking scoring methods are that (a) an original data set must be used to evaluate new test sites, (b) a relatively large number of sites, representing the range of conditions in the region, must be sampled, and (c) scores for all metrics have to be recalculated if metric scores of test sites are outside the range of the original data set. A problem unique to the ranking method is that the method will not identify skewed metric data. 
DISCUSSION OF LANDSCAPE VARIABLES CORRELATED TO THE IEI

Individuals familiar with specific ecoregions and related ecological processes can rationally develop ecological expectations for most landscape variables. Such expectations can then be used to evaluate the effectiveness for newly developed indices (Halliwell and others, 1999). The IEI was highly correlated to two landscape variables that could influence the potential for contaminants to enter MAP streams: the percentage of Holocene deposits in the basin and insecticide use rates. Stream basins east of Crowleys Ridge and stream basins in Arkansas west and south of Crowleys Ridge having the highest (best) IEI scores, consistently had a lower percentage of Holocene deposits and lower cotton insecticide use rates than stream basins in Louisiana and Mississippi, which had the lowest IEI scores (figs. 9, 10, and 11).

Differences in geologic properties of stream basins in the MAP probably influence how clay particles and contaminants in agricultural runoff are physically removed (or filtered) and chemically altered. Areas in the MAP with high percentages of Holocene deposits tend to be more turbid, have higher nutrient and pesticide concentrations in water, have higher concentrations of organochlorine pesticides in fish tissue, and have biological communities that are more impaired than areas with high percentages of Pleistocene deposits (Kleiss and others, 2000). As indicated by data collected in this study, geological properties are a major consideration for how the MAP (ecoregion) is being further subdivided (Jim Omernik, U.S. Environmental Protection Agency, written commun., October 2002).

Retrospective analysis indicates that numerous fish kills have occurred as a result of insecticide applications in both Louisiana and Mississippi (Mississippi Department of Environmental Quality, 1996; McPherson, 1996). This information, coupled with the strong relation between IEI scores and cotton insecticide use rates, suggests that cotton insecticide use may also influence ecological integrity of MAP streams, particularly in these two States. During the past few decades there has been a shift in use from insecticides that persist in the environment (organochlorine compounds) to less persistent forms (organophosphates and synthetic pyrethroid compounds); however, most insecticides, regardless of the form, remain toxic to fish and other biota at low concentrations. The short half-life of most insecticides in use today make it difficult to quantify the ecological effects of insecticides on MAP streams; however, it is known that insecticide-induced fish kills often occur when insecticides are applied in mid-summer immediately prior to rain events. In 1994, the Mississippi Department of Environmental Quality investigated five fish kills in the MAP where the cotton insecticide, profenofos, was detected in dead fish and was suspected to have caused the kill (Mississippi Department of Environmental Quality, 1996). In 1996, the Louisiana Department of Agriculture documented 11 fish kills in the MAP that were associated with pesticides and found that the cotton insecticides profenofos (7), endosulfan (2), and azinophos methyl (1) contributed to 10 of those fish kills (McPherson, 1996). Three of the 16 fish kills that were associated with insecticide use in Louisiana and Mississippi in 1994 and 1996 occurred on streams sampled for this study. The number of fish killed during one of those three events was estimated between 150,000 and 200,000.

It is unknown if cotton insecticide use is higher in Louisiana and Mississippi because of climatic differences (pests would be more prevalent in the warm, subtropical climate) or because of differences in farming practices. Regardless of why insecticide use rates are higher in the southern MAP, the fact that rates are higher in this area could partially explain why sites in Louisiana and Mississippi generally have much higher concentrations of DDT in fish tissue than sites in Arkansas and Missouri (Kleiss and others, 2000).

The effects of channelization on fish communities in MAP streams within Arkansas have been documented (Mauney and Harp, 1979; Holt and Harp, 1993; Bill Keith, Arkansas Department of Environmental Quality, written commun., 2000), and one would expect that ecological integrity in the MAP would be related to habitat quality. Habitat variables measured in this large-scale study were not well correlated to the IEI, although habitat quality did vary within the three $a$ priori classifications. Only nine of the 36 streams studied had a majority of their stream channels unchannelized, and six of those streams were in Arkansas west and south of Crowleys Ridge. Streams west and south of Crowley's Ridge also had more bottomland hardwoods adjacent to the stream channels than other MAP streams. Given these differences, it is probable that differences in habitat were also partially responsible for ecological differences between sites in Arkansas west and south of Crowley's Ridge and sites in the two other a priori classifications. 


\section{SUMMARY}

A multimetric index was developed using data collected at 36 sites in the Mississippi Alluvial Plain Ecoregion (Omernik, 1987), an area where few ecological studies have been conducted. Index results indicate that sites in the northern half of the study unit (in Arkansas and Missouri) were less degraded than sites in the southern half of the study unit (in Louisiana and Mississippi). Of 148 landscape variables that were compared to the index results, the percentage of Holocene deposits and cotton insecticide use rates had the highest correlations to index of ecological integrity results. Results of this study indicate that the amount of Holocene deposits and cotton insecticide use rates partially explain differences in ecological conditions throughout the Mississippi Alluvial Plain Ecoregion. As indicated by data collected in this study, geological properties are a major consideration for how the Mississippi Alluvial Plain Ecoregion is being further subdivided (Jim Omernik, U.S. Environmental Protection Agency, written commun., October 2002).

\section{REFERENCES}

Arkansas Agricultural Statistics Service, 1996, Arkansas agricultural statistics for 1995: Arkansas Agricultural Experiment Station, University of Arkansas Report Series 334, $60 \mathrm{p}$.

Arkansas Department of Pollution Control and Ecology, 1987, Physical, chemical and biological characteristics of least-disturbed reference streams in Arkansas' ecoregions: $685 \mathrm{p}$.

Barbour, M.T., Gerritsen, J., Synder, B.D., and Stribling, J.B., 1999, Rapid bioassessment protocols for use in streams and wadeable rivers: periphyton, benthic macroinvertebrates, and fish: Washington, D.C., U.S. Environmental Protection Agency Office of Water, various pagination.

Barks, C.S., Petersen, J.C. and Usrey, F.D., 2002, Waterquality, biological, and habitat assessment of the Boeuf River Basin, southeastern Arkansas, 1994-96: U.S. Geological Survey Water-Resources Investigations Report 02-4187, 36 p.

Battaglin, W.A., and Goolsby, D.A., 1995, Spatial data geographic information system format on agricultural chemical use, land use, and cropping practices in the United States: U.S. Geological Survey WaterResources Investigations Report 94-4176, $87 \mathrm{p}$.
Caskey, B.J., Justus, B.G., and Zappia, H., 2001, Occurrence of macroinvertebrates at 38 sites in the Mississippi Embayment Study Unit, 1996-99: U.S. Geological Survey Open-File Report 02-190, 8 p.

Coupe, R.H., 2000, Occurrence of pesticides in five rivers of the Mississippi Embayment Study Unit, 1996-98: U.S. Geological Survey Water-Resources Investigations Report 99-4159, 55 p.

Coupe, R.H., 2002, Nitrogen and phosphorus concentrations and fluxes of streams in the Mississippi Embayment Study Unit, 1996-98: U.S. Geological Survey WaterResources Investigations Report 01-4024, 65 p.

Cude, C.G., 2001, Oregon water quality index: A tool for evaluating water quality management effectiveness: Journal of the American Water Resources Association, v. 37 , no. 1 , p. $125-137$.

Davis, W.S. and Simon, T.P., 1995, Biological assessment and criteria: Tools for water resource planning and decision making: Boca Raton, Florida, CRC Press, Inc., 415 p.

Dunnette, D.A., 1979, A geographically variable water quality index used in Oregon: Journal of the Water Pollution Control Federation, v. 51, no. 1, p. 53-61.

Frey, D.G., 1977, Biological integrity of water-an historical approach, in Ballantine, R.K., and Guarraia, L.J., eds., The integrity of water: Washington, D.C., U.S. Environmental Protection Agency, p. 127-140.

Ganasan, V., and Hughes, R.M., 1998, Application of an index of biological integrity (IBI) to fish assemblages of the rivers Khan and Kshipra (Madhya Pradesh), India: Freshwater Biology, v. 40, p. 367-383.

Gianessi, L.P., and Anderson, J.E., 1995, Pesticide use in U.S. crop production - National data report: Washington, D.C., National Center for Food and Agricultural Policy, unpaginated.

Halliwell, D.B., Langdon, R.W., Daniels, R.A., Kurtenbach, J.P., and Jacobsen, R.A., 1999, Classification of freshwater fish species of the Northeastern United States for use in the development of indices of biological integrity, with regional applications, in Simon, T.P., ed., Assessment and approaches for estimating biological integrity using fish assemblages: Boca Raton, Florida, Lewis Press, p. 301-333.

Hill, M.O., 1974, Correspondence analysis: A neglected multivariate method: Applied Statistics, v. 23, p. 340354.

Hill, M.O., 1979, TWINSPAN - A FORTRAN program for arranging multivariate data in an ordered two-way table by classification of individuals and attributes: Ithaca, New York, Cornell University, $90 \mathrm{p}$.

Hill, M.O., and Gauch, H.G., 1980, Detrended correspondence analysis, an improved ordination technique: Vegetatio, v. 42, p. 47-58. 
Hlass, L.J., Fisher, W.L., and Turton, D.J., 1998, Use of the index of biotic integrity to assess water quality in forested streams of the Ouachita Mountains Ecoregion, Arkansas: Journal of Freshwater Biology v. 13, no. 2, p. 181-192.

Holt, A., and Harp, G.L., 1993, Ichthyofauna of the Village Creek System: Proceedings Arkansas Academy of Science, v. 47 , p. 54-60.

Hughes, R.M., 1995, Defining acceptable biological status by comparing with reference conditions, in Davis, W.S., and Simon, T.P., eds., Biological assessment and criteria: tools for water resource planning and decision making: Boca Raton, Florida, Lewis Press, p. 31-48.

Hughes, R.M., Kaufmann, P.R., Helihy, A.T., Kincaid, T.M., Reynolds L., and Larsen, D.P., 1998, A process for developing and evaluating indices of fish assemblage integrity: Canadian Journal of Aquatic Sciences, v. 55, p. $1618-1631$.

Hughes, R.M., and Oberdorff, T., 1998, Applications of IBI concepts and metrics to waters outside the United States and Canada, in Simon, T.P., ed., Assessment and approaches for estimating biological integrity using fish assemblages: Boca Raton, Florida, Lewis Press, p. 7993.

Jongman, R.H.G., Ter Braak, C.J.F., and Van Tongeren, O.F.R., 1995, Data analysis in community and landscape ecology: Cambridge, Cambridge University Press, 299 p.

Justus, B.G., 1998, Ongoing activities of the NAWQA program in the Mississippi Embayment Study Unit, in Daniel, B. Jean, ed., Proceedings of the 1998 Mississippi Water Resources Conference: Raymond, Mississippi, Water Resources Research Institute, p. 174-182.

Justus, B.G., and Caskey, B.J., 2000, Fish occurrence at 38 sites in the Mississippi Embayment Study Unit, 199698: U.S. Geological Survey Open-File Report 99-605, $24 \mathrm{p}$.

Justus, B.G., Bray, D.G., Dossett, A., Hicks, M., Sarver, R.J., and Rogers, M., 2000, Comparison of multi-habitat aquatic macroinvertebrate sampling methods in streams of the Mississippi Alluvial Plain: U.S. Geological Survey Water-Resources Investigations Report 00-4216, $16 \mathrm{p}$.

Karr, J.R., 1981, Assessment of biotic integrity using fish communities: Fisheries, v. 6, p. 21-27.

Karr, J.R., Fausch, K.D., Angermeier, P.L., Yant, P.R., and Schlosser, I.J., 1986, Assessing biological integrity in running waters: A method and its rationale: Illinois Natural History Survey, Special Publication 5, 25 p.

Kentucky Agricultural Statistics Service, 1996, Kentucky agricultural statistics: Louisville, Kentucky, Kentucky Department of Agriculture, $144 \mathrm{p}$.
Kleiss, B.A., Coupe, R.H., Gonthier, G.J., and Justus, B.G., 2000, Water quality in the Mississippi Embayment, Mississippi, Louisiana, Arkansas, Missouri, Tennessee, and Kentucky, 1995-98: U.S. Geological Survey Circular $1208,36 \mathrm{p}$.

Kovach, W.L., 1998, MVSP - A multivariate statistical package for windows, version 3.0: Pentraeth, Wales, U.K, Kovach Computing Services, 127 p.

Louisiana Agricultural Statistics Service, 1996, Annual crop production summary: Baton Rouge, Louisiana, Louisiana Department of Agriculture and Forestry, $4 \mathrm{p}$.

Mauney, M., and Harp, G.L., 1979, The effects of channelization on fish populations of the Cache River and Bayou DeView: Proceedings Arkansas Academy of Science, no. 33, p. 51-54.

McPherson, J.E., 1996, 1996 Fish kill report: Baton Rouge, Louisiana, Louisiana Department of Agriculture and Forestry, $13 \mathrm{p}$.

Meador, M.R., Hupp, C.R., Cuffney, T.F., and Gurtz, M.E. 1993, Methods for characterizing habitat as part of the National Water-Quality Assessment Program: U.S. Geological Survey Open-File Report 93-408, 48 p.

Merritt, R.W., Cummins, K.W., Berg, M.B., Novak, J.A., Higgins, M.J., Wessell, K.J., and Lessard, J.L., 2002, Development and application of a macroinvertebrate functional-group approach in the bioassessment of remnant river oxbows in southwest Florida: Journal of the North American Benthological Society, v. 21, no. 1, p. 290-306.

Miller, D.L., Leonard, P.M., Hughes, R.M., Karr, J.R., Moyle, P.B., Schrader, L.H., Thompson, B.A., Daniels, R.A., Fausch, K.D., Fitzhugh, G.A., Gammon, J.R., Halliwell, D.B., Angermeier, P.L., and Orth, D.J., 1988, Regional applications of an index of biotic integrity for use in water resource management: Fisheries, v. 13, p. $12-20$.

Minns, C.K., Cairns, V.W., Randall, R.G., and Moore, J.E., 1994, An index of biotic integrity (IBI) for fish assemblages in the littoral zone of Great Lakes' areas of concern: Canadian Journal of Fisheries and Aquatic Sciences, v. 51, p. 1804-1822.

Mississippi Agricultural Statistics Service, 1996, Mississippi agricultural statistics: Jackson, Mississippi, Mississippi Department of Agriculture and Commerce, $73 \mathrm{p}$.

Mississippi Department of Environmental Quality, 1996, Mississippi 1996 water quality assessment, Federal Clean Water Act Section 305(b) Report: Jackson, Mississippi, various pagination.

Missouri Agricultural Statistics Service, 1996, Missouri farm facts: Columbia, Missouri, Missouri Department of Agriculture, $76 \mathrm{p}$. 
Nature Conservancy, 1992, The forested wetlands of the Mississippi River: An ecosystem in crisis: Baton Rouge, Louisiana, 25 p.

Omernik, J.M., 1987, Ecoregions of the conterminous United States, map (scale1:7,500,000): Annuals of the Association of American Geographers, v. 77, no 1, p. 118-125.

Ott, W.R., 1978, Water quality indices: A survey of indices used in the United States: Washington, D.C., U.S. Environmental Protection Agency Office of Research and Development, various pagination.

Petersen, R.C., 1992, The RCE-A riparian, channel, and environmental inventory for small streams in the agricultural landscape: Freshwater Biology, v. 27, p. 295306.

Saucier, R.T., 1994, Geomorphology and quaternary geology history of the Lower Mississippi Valley: Vicksburg, Mississippi, U.S. Army Engineer Waterways Experiment Station, v. I, 398 p.

Shields, F.D., Jr., Knight, S.S., and Cooper, C.M., 1995, Use of the index of biotic integrity to assess physical habitat degradation in warmwater streams: Hydrobiologia, v. 312, p. 191-208.

Simon, T.P., 1999, Assessing the sustainability and biological integrity of water resources using fish communities: Boca Raton, Florida, CRC Press, Inc., 671 p.

Tennessee Agricultural Statistics Service, 1995, Tennessee agricultural statistics: Nashville, Tennessee, Tennessee Department of Agriculture, $195 \mathrm{p}$.

Thelin, G.P., and Gianessi, L.P., 2000, Method for estimating pesticide use for county areas of the conterminous United States: U.S. Geological Survey Open-File Report 00-250, $62 \mathrm{p}$.

United States Department of Agriculture, 1991, State soil geographic data base (STATSGO) data users guide: Soil Conservation Service Miscellaneous Publication 1492, $88 \mathrm{p}$.

United States Department of Commerce, 1995, Monthly station normals of temperature, precipitation, and heating and cooling degree days 1961-1990: Climatography of the United States No. 81, Asheville, North Carolina, National Oceanic and Atmospheric Administration, National Climatic Data Center, 6 p.

United States Department of Commerce, Bureau of Census, 1990, 1990 census of population and housing summary population and housing characteristics-Arkansas, Kentucky, Louisiana, Mississippi, Missouri, and Tennessee: $26 \mathrm{p}$.

United States Geological Survey, 2001, http://tapestry.usgs.gov/Default.html, A tapestry of time and terrain: The union of two maps - geology and topography: Homepage of the USGS Information Services, Map Distribution.
Vogelman, J.E., Sohl, T., and Howard, S.M., 1998, Regional characterization of land cover using multiple sources of data, photogrammetric engineering and remote sensing, v. LXIV, no. 1, p. 45-57.

Wetzel, R.G., and Likens, G.E., 1991, Limnological analyses (2d ed.): New York, New York, Springer-Verlag, 391 p. 
